\title{
Heterogeneous structure of the lithosphere in the Black Sea from a multidisciplinary analysis of geophysical fields
}

\author{
(C) V. I. Starostenko, O. M. Rusakov, I. K. Pashkevich, R. I. Kutas, I. B. Makarenko, \\ O. V. Legostaeva, T. V. Lebed, A. S. Savchenko, 2015
}

\author{
Institute of Geophysics, National Academy of Sciences of Ukraine, Kiev, Ukraine \\ Received 14 October 2014 \\ Presented by Editorial Board Member T. P. Yegorova
}

\begin{abstract}
Magnetic, gravity, geothermal, seismic and tomographic data from the lithosphere were first jointly examined. A multidisciplinary interpretation has resulted in a new and consistent model for lithospheric density, magnetic, thermal and velocity heterogeneities. Faults of different orders for the crystalline crust have been mapped in details. Large deep fault zones were recognized. Among them is the most prominent Odessa-Sinop-Ordu (OSO) fault zone, which played a key role in the opening and development of the Black Sea Depression. A fundamental difference was revealed between the crustal and mantle structure and geophysical parameters of the Western Black Sea Basin (WBSB) and Eastern Black Sea Basin (EBSB). These dissimilarities are in the size of «non-granitic» crust, pattern and intensity of heat flow, topography of the lower boundary of the thermal lithosphere, mantle seismic velocity and structure of magnetic and residual gravity anomalies. Based on new information it was demonstrated that the WBSB and EBSB were diachronously formed on two large distinct continental blocks with independent post-rift development of the sub-basins. The rifting of the western sub-basin commenced earlier than that of the eastern one. The EBSB is characterized by younger thermal activity than the WBSB and consequently it was stabilized later. The Mid Black Sea High (MBSH) is not a single tectonic unit but is formed by two ridges of various crystalline crustal structure and age shifted relative to each other by the faults of the OSO zone.
\end{abstract}

Key words: The Black Sea basins, magnetics, gravity, heat flow, fault tectonics, seismic tomography, lithosphere heterogeneity.

Впервые проведен общий анализ магнитных, гравитационных, геотермических, сейсмических и томографических данных о литосфере Черного моря. В результате комплексной интерпретации получена новая и согласованная модель плотностной, магнитной, термальной и сейсмической неоднородностей литосферы. Построена подробная карта разломов консолидированной коры разных рангов. Выявлены зоны глубинных разломов. Среди них наиболее примечательна зона разлома Одесса-Синоп-Орду, игравшая ключевую роль в раскрытии и развитии Черноморской впадины. Выявлены фундаментальніе различия в строении и геофизических параметрах коры и литосферы Западно- и Восточно-Черноморской впадин. Эти различия заключаются в размере площади «безгранитной» коры, структуре и интенсивности теплового потока, топографии нижней границы термальной литосферы, особенностях магнитного и остаточного гравитационного полей. На основе новой информации показано, что Западно- и Восточно-Черноморская впадины сформировались в разное время на двух различных крупных блоках континентальной коры с независимым пострифтовым развитием суббассейнов. Рифт в западном бассейне образовался раньше, чем в восточном. Восточно-Черноморская впадина отличается более молодой термической активностью, чем Западно-Черноморская, которая стабилизировалась позже. Центрально-Черноморское поднятие не представляет собой единую тектоническую единицу, а сформировано двумя хребтами с различным строением консолидированной коры разного возраста, которые смещены друг относительно друга разломами зоны Одесса-Синоп-Орду.

Ключевые слова: Черноморский бассейн, магнетизм, гравитация, тепловой поток, тектоника, сейсмическая томография, литосферная неоднородность.

1. Introduction. The interest in the Black Sea geology is determined by its key role in understanding the tectonic evolution of the middle Tethyan Realm and its hydrocarbon potential for the coastal countries. Despite abundant consideration that the Black Sea is a back-arc basin, there are still strong debates about the details of its origin and evolution [e.g. Zonenshain, Le Pichon, 1986; Finetti et al., 1988; Okay et al., 1994; Spadini et al., 1996; Cloetingh et al., 2003; Nikishin et al., 2003; Kutas, 
2003; Besutiu, Zugravescu, 2004; Afanasenkov et al., 2007; Hippolyte et al., 2010; Çinku et al., 2013; Kaymakci et al., 2014; Nikishin et al., 2015a, b]. The key differences among the models for kinematics history of the region address the timing for opening of the Black Sea and the determining of the location, number, size and kinematics of original Neotethyan fragments related to the tectonic development of the region.

The present-day tectonic setting of the Black Sea is mainly derived from subsurface information, such as seismic stratigraphy and deformation of marine sediments, sparse deep sounding, seismic and wide-angle seismic surveys and tectonic-sedimentary observations in adjacent land areas [Tugolesov et al., 1985; Finetti et al., 1988; Okay et al., 1994; Robinson, 1997; Afanasenkov et al., 2007; Scott et al., 2009; Shillington et al., 2009; Hippolyte et al., 2010; Yegorova et al., 2010 among others]. Thermo-mechanical and gravity modeling, seismic tomography have revealed the different lithospheric structure as a whole in the Western and Eastern Black Sea Basins without addressing separate and distinct tectonic elements of the crust [Spadini et al., 1996; Cloetingh et al., 2003; Bugaenko et al., 2008; Nikishin et al., 2011; Yegorova et al., 2010, 2013]. The available information is however insufficient to determine comprehensively the relationship between the geological units in the crust and upper mantle that governs substantially the tectonic setting and evolution of the basins.

The purpose of this work is to present the results of the first joint interpretation of gravity and magnetic fields, heat flow and lithospheric seismic velocity and to shed new light on to the deep structure of the Black Sea Depression and coupling near-surface tectonics and lithospheric features at a regional scale. A new approach was applied to reveal lithospheric heterogeneities, in particular, using residual gravity of the crystalline crust and magnetic observed fields. Such a combination makes it possible to evaluate irregularities in the crystalline crust and mantle as well as a penetration depth of faults.

The study is based on four approaches for interpreting geophysical fields. The magnetic field was examined to delineate major faults and to reveal magnetic heterogeneities in the crystalline crust. The thermal regime of the lithosphere was derived from interpretation of the most detailed heat flow data. Three-dimensional density modeling of water and sedimentary layers was conducted for obtaining gravity effect of the crystalline crust and of the mantle for mapping major deep faults. Seismic information was used to find the relation between deep and sub-surface tectonic features. All the data were summarized to give internally consistent image of geophysical heterogeneities beneath the sedimentary cover. Finally, new complementary information was employed to discuss the clear differences in the structure and physical parameters of the lithosphere in the WBSB and EBSB and the timing for the opening of these tectonic elements.

2. Tectonic setting. Fig. 1 shows the tectonic setting of the Black Sea and surrounding regions [Starostenko et al., 2010]. The study area is tectonically very complex and heterogeneous. The Black Sea is surrounded by the late Cenozoic mountain ridges of Crimea $(\mathrm{Cr})$, Caucasus (C), Pontides (Pon) and Balcanides (Bal) and older features of different origins and ages of the East European Craton (EEC), Scythian Platform (SP), Dobrogea (D), Moesian Platform (MP), StrandjaSakarya (S-S) and Achara-Trialeti zones (A-T). It is composed of two sub-basins, which include various features characterized by different genetic and kinematic histories such as the Andrusov (An), Arkhangelsky (Ar) and Shatsky (Sh) Ridges, Sorokin (Sor), Karkinit (Kr) and Tuapse (T) Troughs.

Before plunging into a discussion of different disputable models for the opening of the Black Sea Basin, we analyze only the relationship between the marine tectonic elements and their extension on land. The strikes of major faults and boundaries of the structural elements on the northern and southern margins are concordant with these on the present-day boundaries of the sub-basins. In the Eastern Black Sea reverse/thrust faults of the northwestern and northeastern strikes constitute a single system with the faults of the Greater Caucasus and Crimea. In the Western Black Sea, west of the Odessa-Sinop (OS) fault a similar conformity is not recognized. The largest faults of the North Dobrogea (ND) Orogen and MP are orthogonal to the basin boundaries and sub parallel to the OS fault, Neo Alpine (NA) thrust front and presumed southeastern continuation of the Teisseyer-Tornquist Zone (TTZ) with general trend shown in Fig. 1.

The OS fault is considered an interregional tectonic feature extending from the EEC to the Pontides [Chekunov, 1987; Kravchenko et al., 2003, Starostenko et al., 2010]. It is this fault that is likely to represent a major boundary between the WBSB and EBSB. The largest uplifts and troughs of the EBSB relate to the faults with northwestern and northeastern strikes.

3. Data characterization and interpretation approaches. 3.1. Free air gravity anomalies. We 
present a new $5 \times 5 \mathrm{~km}$ grid digital map of freeair anomalies with a contour interval of $10 \mathrm{mGal}$, which is based only on ship-track measurements (Fig. 2). They were made during 55 years by various industrial and academic organizations from the Former Soviet Union including the Institute of Geophysics of the National Academy of Sciences of Ukraine [Starostenko et al., 2004a]. The map is much more detailed and informative than those of published earlier [Belousov et al., 1988; Spadini et al., 1996; Starostenko et al., 2004a; Sandwell, Smith, 2009; Yegorova, Gobarenko, 2010].

In the gravity map, the dominant features are two vast size oval-like anomalies in the deep-water basins where rather small negative and positive values are registered up to $\pm 20 \mathrm{mGal}$. Higher negative field (up to tens of milligals) was measured in the transitional zone between the central part of the sea and on the shelf. For example, there exists an almost circular negative low value of over -60 mGal near the Bulgarian shelf. An elongated gravity minimum of similar amplitude is centered over the Sor Trough (southeast of the Crimean Peninsula). A large gravity low value about $-90 \mathrm{mGal}$ trends parallel to the Greater Caucasus offshore. A number of regional and local anomalies of opposite signs are clearly observed on the periphery of the Black Sea and on the MBSH. Except for the NW shelf, they extend into land.

In 3D gravity modeling we applied the efficient methodology described in details elsewhere [Hammer, 1963; Starostenko et al., 2004a]. A principal advantage of this approach over others is possibility of quantitative estimating regional and local differences between observed and modeled fields over large areas by determining gravity contribution within a single reference system. Gravity calculations were made using an automated input scanned data to a computer in the form of isoline maps [Starostenko, Legostaeva, 1998].

The efficacy of this approach can be exemplified by the gravity model of Moho depth for the Black Sea [Starostenko et al., 2004a, Fig. 14]. The map of the crust-mantle boundary remains so far not

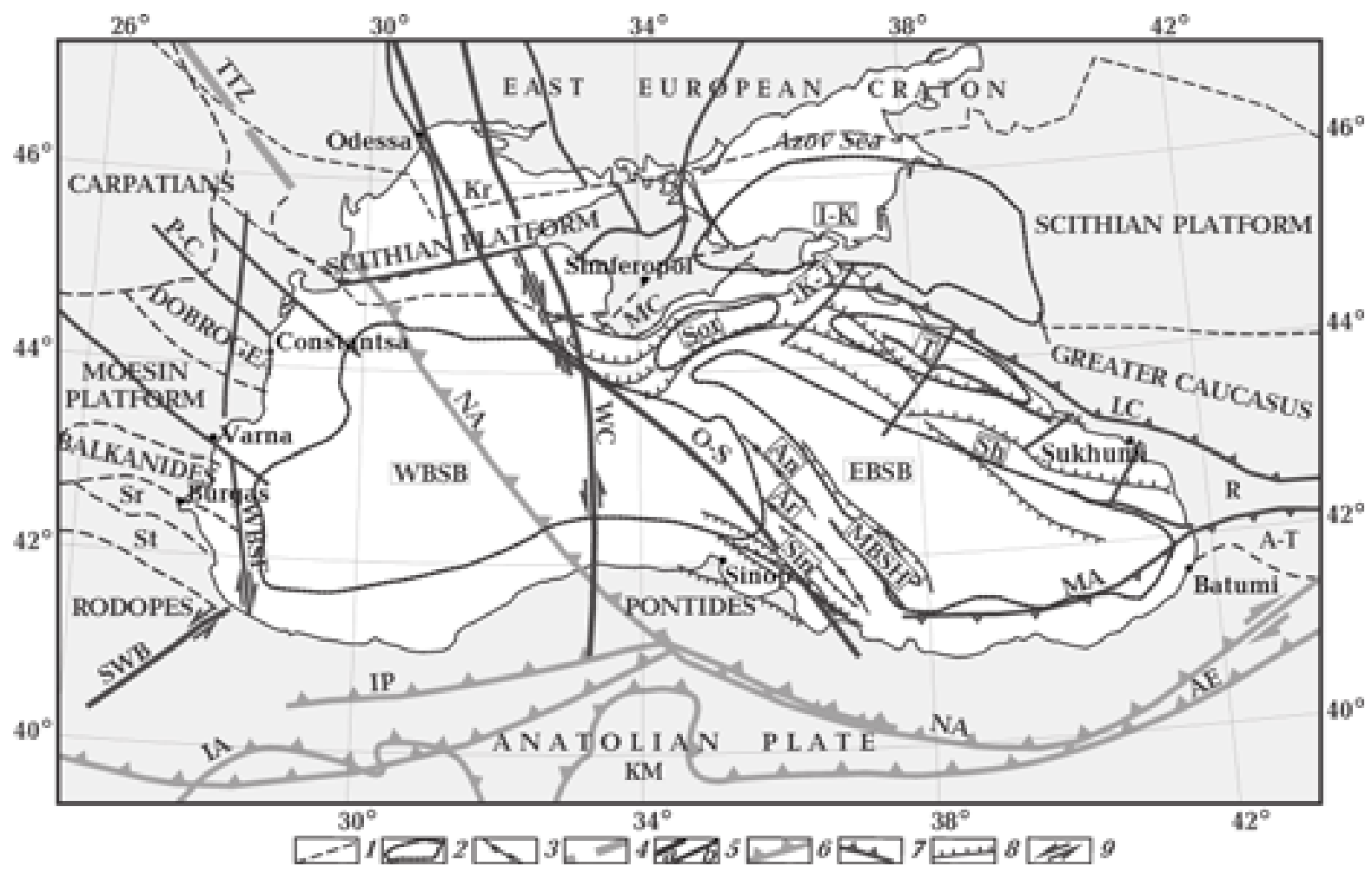

Fig. 1. Major tectonic units of the Black Sea and adjacent areas [Modified from Starostenko et al., 2010]: 1 - boundaries of tectonic elements (Sr — Srednogorie, St — Strandja, R — Rioni Depression, A-T — Achara-Trialeti fold zone, KM — Kirşehir massif); 2 - major features (WBSB — Western Black Sea Basin, EBSB — Eastern Black Sea Basin, MBSH — Mid Black Sea High, I-K — Indol-Kuban Trough, Sor — Sorokin Trough, K-T — Kerch-Taman Trough, Kr — Karkinit Trough, T — Tuapse Trough, Sin - Sinop Tough, Sh — Shatsky Ridge); 3 - axes of the Andrusov (An) and Arkhangelsky (Ar) Ridges; 4 - supposed southeastern prolongation of the Teisseyre-Tornquist zone (TTZ); 5 - faults of the first $(a)$ and second $(b)$ orders (O-S - Odessa-Sinop, WC - Western Crimea, WBSF — Western Black Sea, SWB — Southwestern Balkans, P-C — Peceneaga-Camena); 6 - sutures (NA - Neo - Alpine Thrusts Front, IP — Inner Pontides, IA — Izmir-Ankara, AE — Ankara —Erzincan); 7 - overthrusts (LC — Lesser Caucasus, MA - Middle-Alpine Thrusts); 8 - normal faults; 9 - slight slip directions. MC — Mountains Crimea. 


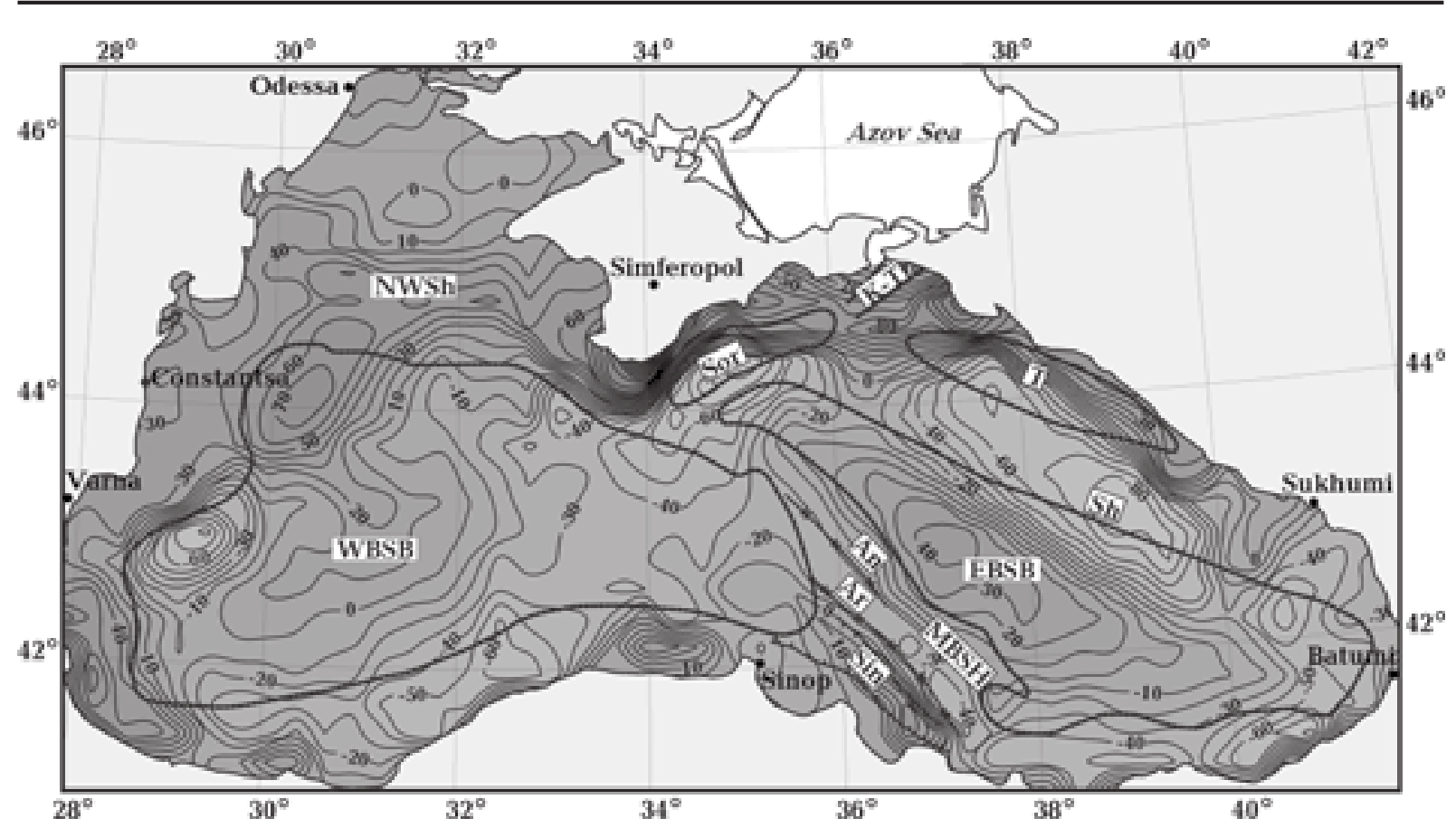

Fig. 2. Free-air gravity anomaly map of the Black Sea. NWSh — NW Shelf of the Black Sea. For other symbols and abbreviations see Fig. 1. Lines I-I and II-II are the interpretation profiles (see Fig. 16). Units are in mGal.

only the most detailed, it is supported by new 2D seismic information. This is the only map where all major crustal elements are adequately delineated in contrast to those developed from interpolation of sparse DSS profiles. The reinterpretation of DSS data (regional profiles 25, 28 and 29) using tomographic inversion of the first arrival of seismic waves and a ray tracing technique resulted in coincidence of Moho depths within an accuracy of seismic records [Kozlenko et al., 2009; Yegorova et al., 2010]. This is really the case of the NW shelf, central part of the Black Sea sub-basins, Sor Trough and MBSH. Wide-angle seismic data revealed the thinned continental crust beneath the Ar Ridge of ca. $30 \mathrm{~km}$ thick [Shillington et al., 2009, Line 3; Scott, 2009] that is equal to the value on the map of [Starostenko et al., 2004a]. This crustal basement is thought to be similar with Precambrian units from the Transcaucasus domain [Saintot et al., 2006].

The ultimate objective of determining sedimentary density is to delineate fault tectonics of the crystalline crust in more details than in using directly the observed field. The point is that gravity effect of sedimentary cover in the Black Sea produces ca. $70 \%$ of that associated with the crystalline crust [Starostenko et al., 2004a]. Its influence greatly masks characteristic peculiarities of the observed gravity field related to the crystalline crust. Linear steep gradients in gravity field commonly relate to abrupt density contrasts across tectonic faults. The horizontal-gradient method is traditionally used to enhance their expression because the steepest parts of the gravity field are not necessary obviously seen on maps [e.g. Grant, West, 1966; Smith et al., 2002; Starostenko et al., 2005; Aryamanesh, 2009]. Here we briefly discuss our approach, which is based on common principals of gradient studies.

To obtain maximum horizontal gradients with sufficient precision a set of curves of residual gravity of the crystalline crust have been drawn across the strike of the dominant trends of residual anomalies. Based on these graphs, gradients were first derived by visually determining points of tangency [Grant, West, 1966] and then using software for the 3D study [Starostenko, Legostaeva, 1998].

For mapping the faults from the residual freeair gravity field the following criteria are used. Linear gradient zones are associated with faults bordering crustal blocks of different density or steps in crustal topography, bounding blocks of the same density. Linear gravity maxima and minima indicate basic and ultrabasic dykes and crush belts in rocks respectively, which are associated with faults.

3.2. Total field magnetic anomalies. Study of total field magnetic anomalies has a long history in the Black Sea. Many industrial companies and academic institutions from the Former Soviet Union have performed air- and marine borne sur- 


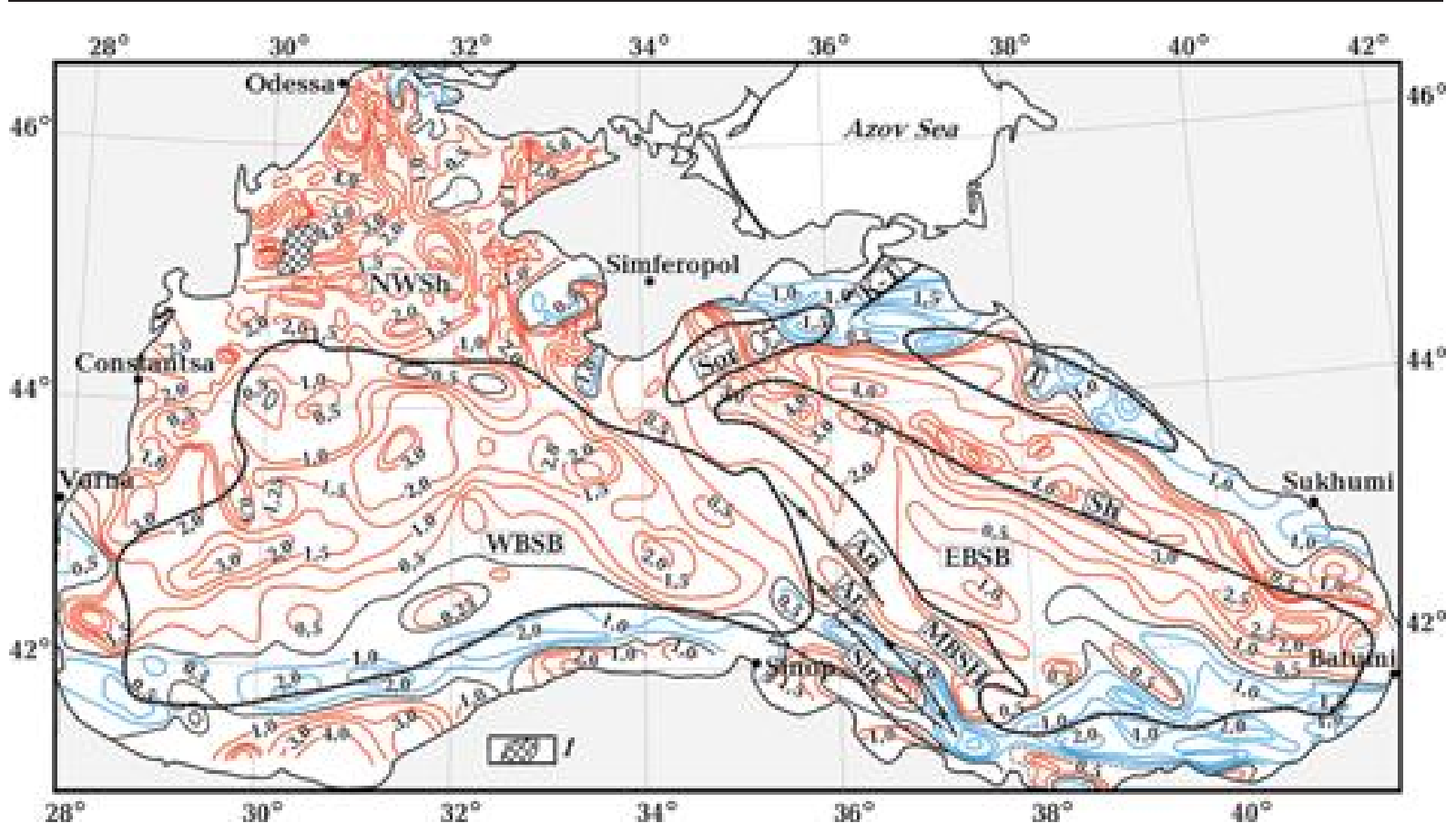

Fig. 3. Total field magnetic anomaly map of the Black Sea: 1 - high differentiated field. Units are in $100 \mathrm{nT}$, isolines: red positive, blue — negative. Magnetic anomalies: WBS - Western Black Sea, OS — Odessa — Sinop, AB — Alushta — Batumi. For other symbols and abbreviations see Fig. 1, 2.

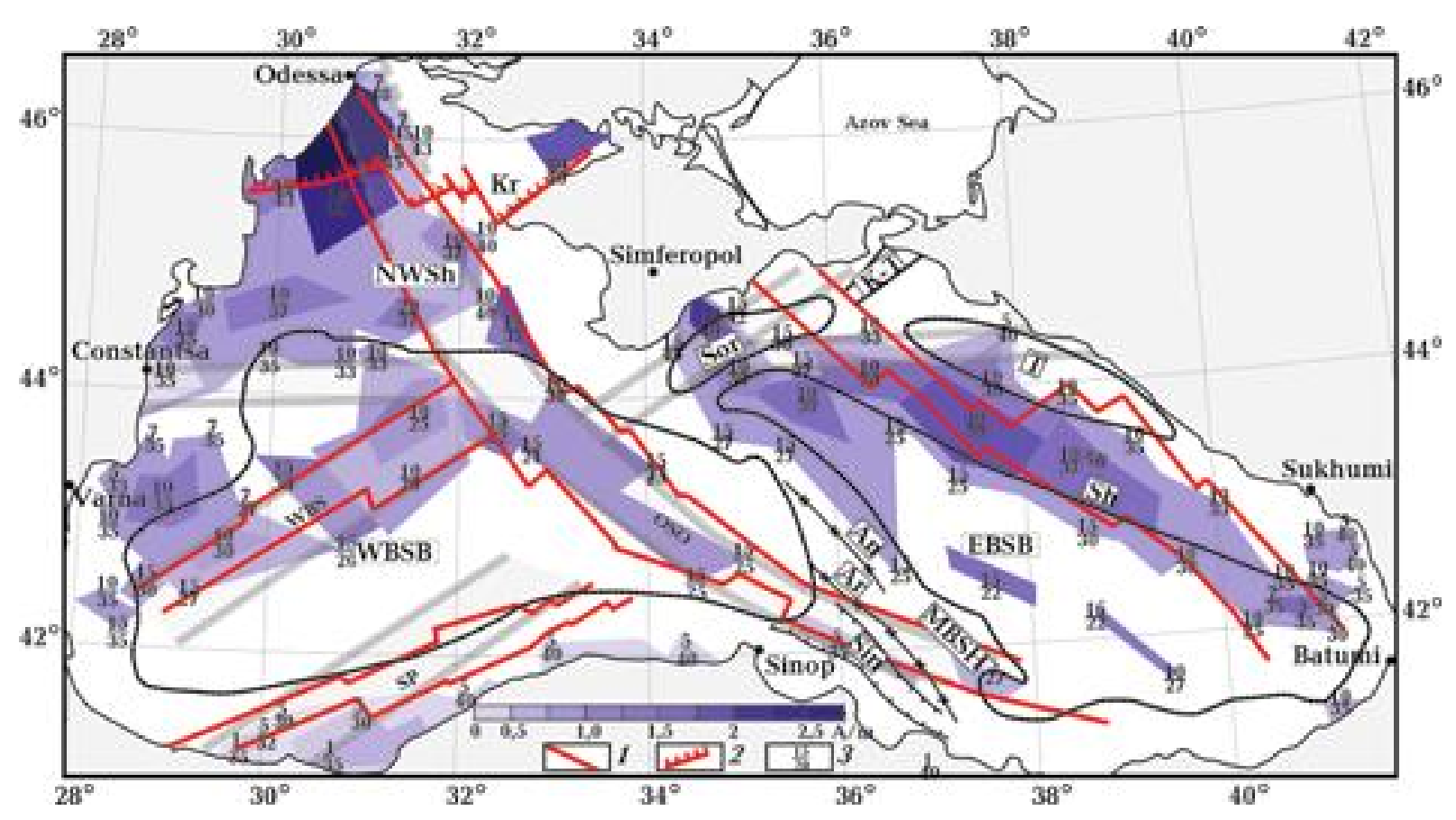

Fig. 10. Magnetic model for the crystalline crust of the Black Sea: 1 - main fault zones (WBS - Western Black Sea, OSO Odessa-Sinop-Ordu, AB - Alushta-Batumi, SP — subparallel to the Inner Pontides suture), 2 - EEC boundary, 3-depths to the upper (nominator) and to the lower (denominator) edges of magnetic sources. For other symbols and abbreviations see Fig. 1, 5, 11.

veys using flux gate and proton magnetometers in different line spacing. As a result, several maps of a different scale and accuracy have been compiled
[Starostenko et al., 2010]. For this work a composite map based on these results was digitized on a regular grid of $5 \times 5 \mathrm{~km}$. Anomalies $(\Delta \mathrm{T})_{\mathrm{a}}$ have been 


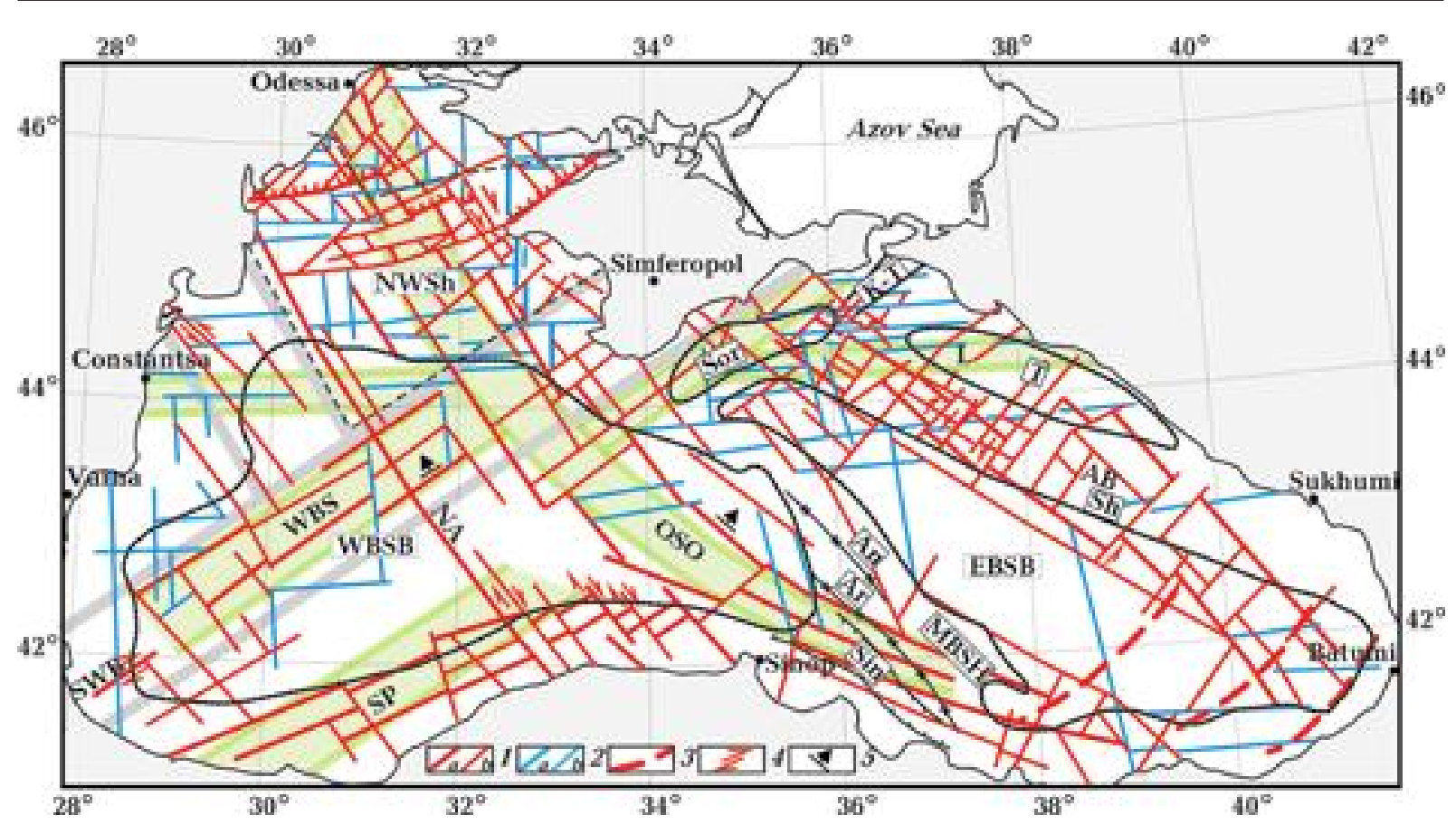

Fig. 11. Map of the crystalline crust faults derived from the anomaly magnetic and residual gravity fields [Modified from Starostenko et al., 2010]: 1 - diagonal faults system of the first (a) and second (b) orders, 2 - orthogonal faults system of the first $(a)$ and second (b) orders, 3 - proposal transform faults by [Shillington et al., 2009], 4 - relative displacement along faults, 5 - supposed dip direction. L — Latitudinal fault zone. For other symbols and abbreviations see Fig. 1, 5.

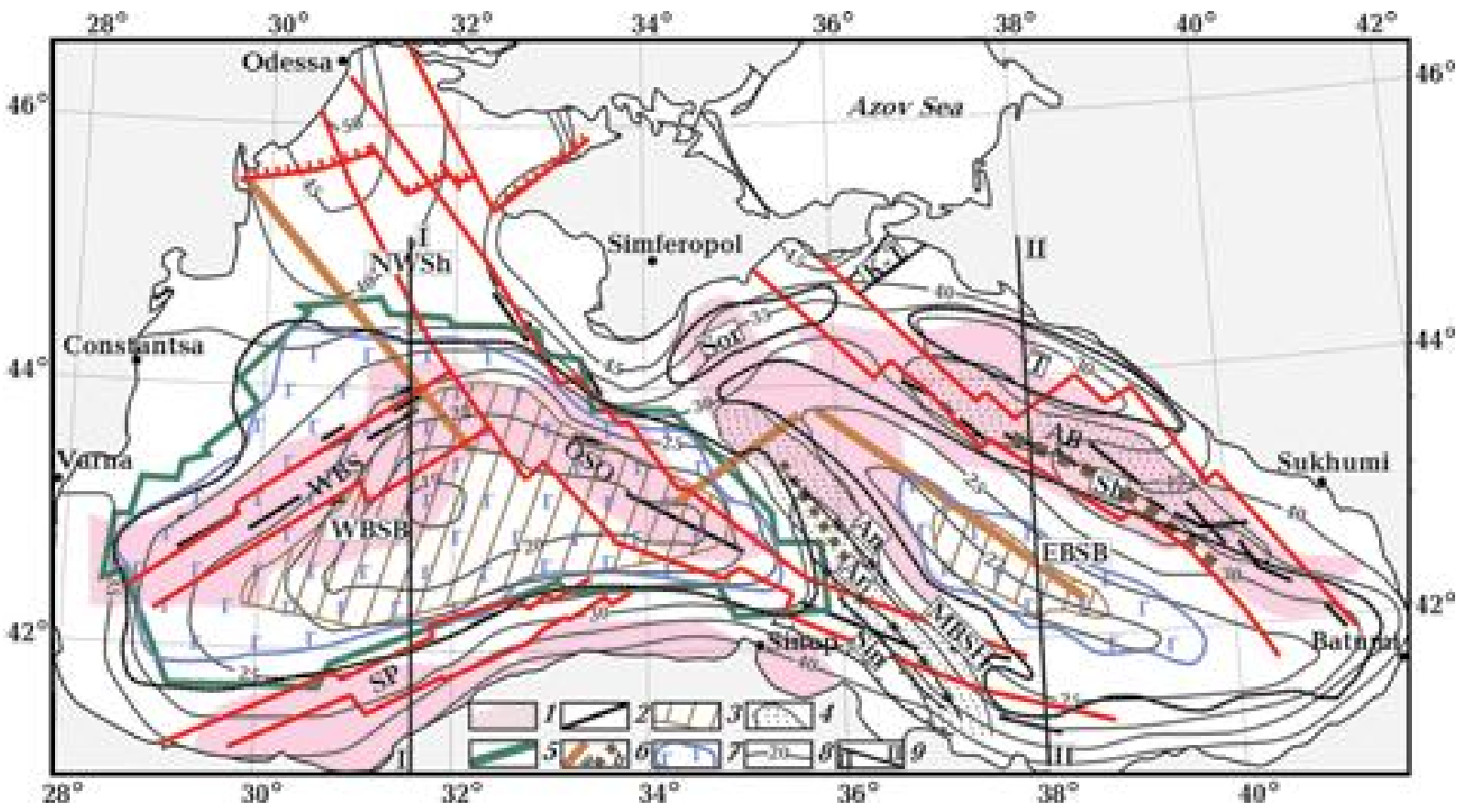

Fig. 15. Relationship between crustal composition, gravity residuals, regional magnetic anomalies and depths to the base crust [Modified from Starostenko et al., 2010]: 1 - positive regional magnetic background, 2 - axes of positive local magnetic anomalies, 3, 4-gravity effect of the crystalline crust (3- maximums, 4- minimums), 5- configuration of the WBSB is from residual gravity field, 6 - relative maximums $(a)$ and minimums $(b)$ of the gravity mantle component, 7 - «non-granitic» crust, 8 - crust base depth $(\mathrm{km}), 9$ - cross-section lines. See Fig. 1, 11, 16 for other symbols and abbreviations.

calculated relative to IGRF-2010 (Fig. 3). The map has been slightly simplified to illustrate regional features of the magnetic pattern. Some impor- tant local anomalies have been however analyzed usingmaps of the larger scale.

As a rule, magnetic anomalies of the Black Sea 
shelf coalesce with those of the adjacent land. The strikes and intensity of the marine anomalies change drastically in approaching deep basins. There exist two major directions of the magnetic pattern in the deep sub-basins: northwestern and northeastern. The first is characteristic of the Western Black Sea anomaly (WBS) the second coincides with Alushta-Batumi anomaly (AB) in the Eastern basin and positive anomaly of OS zone.

The regional WBS anomaly almost occupies the central part of the WBSB. It consists of several maxima which are observed against the regional background of the magnetic field (intensity is ca. $50 \mathrm{nT}$ ). There exists the most intensive local anomaly at the junction between these trends. The SW flank of the anomaly is formed by a number of elongated local anomalies with an intensity of up to $350 \mathrm{nT}$ shifted relative to each other. Much weaker intensity is characteristic of the anomaly of the OS fault zone with a SE trend. It is composed of several almost isometric anomalies observed against the regional background of 100-150 nT intensity.

To the south of these positive magnetic anomalies, there is a broad minimum of the field with several local linear weak maxima, which are parallel to axes of the anomalies in the southwestern part of the WBS anomaly. The NW part of the WBSB is characterized by a positive background magnetic field.

In the EBSB the magnetic pattern differs in morphology from that one of the WBSB. Here the $\mathrm{AB}$ magnetic anomaly dominates, which is also being composed of regional and local components. The regional background and local anomalies are however more intensive than those ones of the WBS anomaly. Their intensities are 200 and 600 nT respectively. The local anomalies are arranged in an echelon-like style displaced eastward one to another. Structurally the NW portion of the AB anomaly coincides with the Shatsky Ridge while its SE part is located on the edge of the EBSB.

In the south of this anomaly belt there is a broad magnetic low. There are a number of linear weak local positive anomalies against its background. Their trends are similar to those ones of the SE of the $\mathrm{AB}$ anomaly.

The MBSH that includes the An and Ar Ridges morphologically and magnetically separates the WBSB and EBSB. The marginal part of the positive regional magnetic background covers the An Ridge. The Ar Ridge is partly marked by the magnetic minimum. The axis of the Sin Trough is recorded by a positive magnetic anomaly continuing outside its boundary to the southeast.

In modeling magnetic sources are assumed to occur in the crystalline crust because in the Black Sea the Curie temperature of the magnetite $\left(578^{\circ}\right.$ C) is reached mainly below the Moho or sometimes above it [Starostenko et al., 2014]. The sedimentary cover is practically nonmagnetic on the NW shelf [Bezverkhov, 1988] and in the uppermost 1 $\mathrm{km}$ section of the 380 borehole [Ross, 1978]. In the deep-water part magnetic susceptibility information is not available. In another way, values of magnetic susceptibility of samples can be used from the adjacent onshore because marine seismic stratigraphy is similar to that exposed on land [see for example, Rangin et al., 2002; Khriachtchevskaia et al., 2009; Hippolyte et al., 2010; Georgiev, 2012]. They do not exceed mostly $(30-40) \times 10^{-5}$ SI on the conjugate margins of the Black Sea in the Pon and Cr [Kaymakci et al., 2003; Guzhikov et al., 2012].

The model-making procedure is as follows. For initial approximation, crystalline crust was represented by a set of 3D magnetic bodies with different magnetic susceptibility. The computations were made using software on a regular grid of $5 \times 5 \mathrm{~km}$ [Starostenko et al., 2004b]. The starting model has been updated several times to fit adequately the observed and modeled fields. In this case, the total magnetic intensity map has been graphically reduced to reference level for the continental crust of the Black Sea Region.

The horizontal-gradient method (see section 3.1) has been also used to elucidate tectonic faults. Magnetic interpretation in term of faults is based on considering only linear or semi-linear high gradient zones and regular shifts of stripe gradients. As usual, faults and fault zones are revealed fragmentarily as stripes of different width. A combined analysis of signs and their regularities of potential fields made it possible to recognize the orders and systems of faults including displacement along them.

3.3 Heat flow. During 40 years of the last century ca. 500 heat flow assessments were made by many researchers in the sub-bottom sediment layer in the Black Sea. Since 1992 only the Institute of Geophysics of National Academy of Sciences, Ukraine, has performed such determinations obtaining 192 values [Kutas et al., 1998, 1999, 2003, 2005; Kutas, Poort, 2008]. Thermal measurements from 690 stations have been digitized on a regular grid of $15 \times 20 \mathrm{~km}$ and a new heat flow map was compiled with contour interval $10 \mathrm{mWm}^{-2}$ (Fig. 4). Description of input data and methodology of compiling a map are presented elsewhere [Kutas, 2010].

Heat flow values are subjected to many surface and deep factors. The values are therefore very 
sensitive to fluctuations in topography, bottomwater temperature, sedimentation, climate changes, thermophysical parameters and radiogenic heat sources. Procedures of corrections for these effects in the Black Sea were repeatedly described [see for examples, Kutas, Tsvyashchenko, 1993; Kutas, 2003; Galushkin et al., 2006].

Several different thermal domains are distinguished in Fig. 4. The central parts of the WBSB and EBSB are dominated by low heat flow density of $20-40 \mathrm{mWm}^{-2}$. In their deepest parts, the heat flow does not exceed $30 \mathrm{mWm}^{-2}$. The area of low values occupies mainly the WBSB where the "granitic» layer of the crust is absent. A mean value of heat flow for the sub-basin is $32 \pm 5 \mathrm{mWm}^{-2}$. In the western part the low heat flow extends to land area. The heat flow pattern of the EBSB is more differentiated. Here heat flow values vary from $18-20$ to $50-60 \mathrm{mWm}^{-2}$. Several relatively small anomalies are observed on the background field. The most spacious anomaly of $40-50 \mathrm{mWm}^{-2}$ occurs in the central EBSB. The An Ridge is characterized by $25-70 \mathrm{mWm}^{-2}$. The most intensive anomaly of $50-70 \mathrm{mWm}^{-2}$ is observed over the NW An Ridge.

On the periphery of the sea, heat flow changes mainly in the range of $20-150 \mathrm{mWm}^{-2}$. An abnormal heat flow value $\left(372 \mathrm{mWm}^{-2}\right)$ was however recorded over the Dvurechensky mud volcano in the Sor Trough. It is marked by red star in Fig. 4 $\left(44^{\circ} 17,1^{\prime} \mathrm{N}, 34^{\circ} 58,9^{\prime} \mathrm{E}\right)$.

In the Black Sea adjoining land geologic units influence a distribution of heat flow. Its variation is controlled by geodynamic peculiarities and geological history of adjacent tectonic features on land. Increased heat flows are characteristic of the submarine continuation of the A-T zone, Bal, Great Caucasus (GC), Sor Trough, SP etc (see Fig. 1) Significant variations in heat flow result from different ages of tectonic elements and/or repeated tectonic rejuvenations at different time. Substantial variations in heat flow are characteristic of troughs and uplifts on the periphery of the Black Sea. Heat flow fluctuates from 20 to hundreds of $\mathrm{mWm}^{-2}$ in the Sor and T Troughs. The low heat flow values dominate while high values form local anomalies. The latter is associated with near flank faults, diapiric folds and mud volcanism. A small increase in heat flow is observed above the basement uplifts.

In young sedimentary basins the thermal field is non-stationary due to seasonal and longtime climate changes, tectonic activity, basement subsidence and sedimentation. It implies that their thermal regime can be reconstructed only taking into consideration an evolution of the basin. The study of the present-day thermal regime of the Black Sea lithosphere is based on assumption that

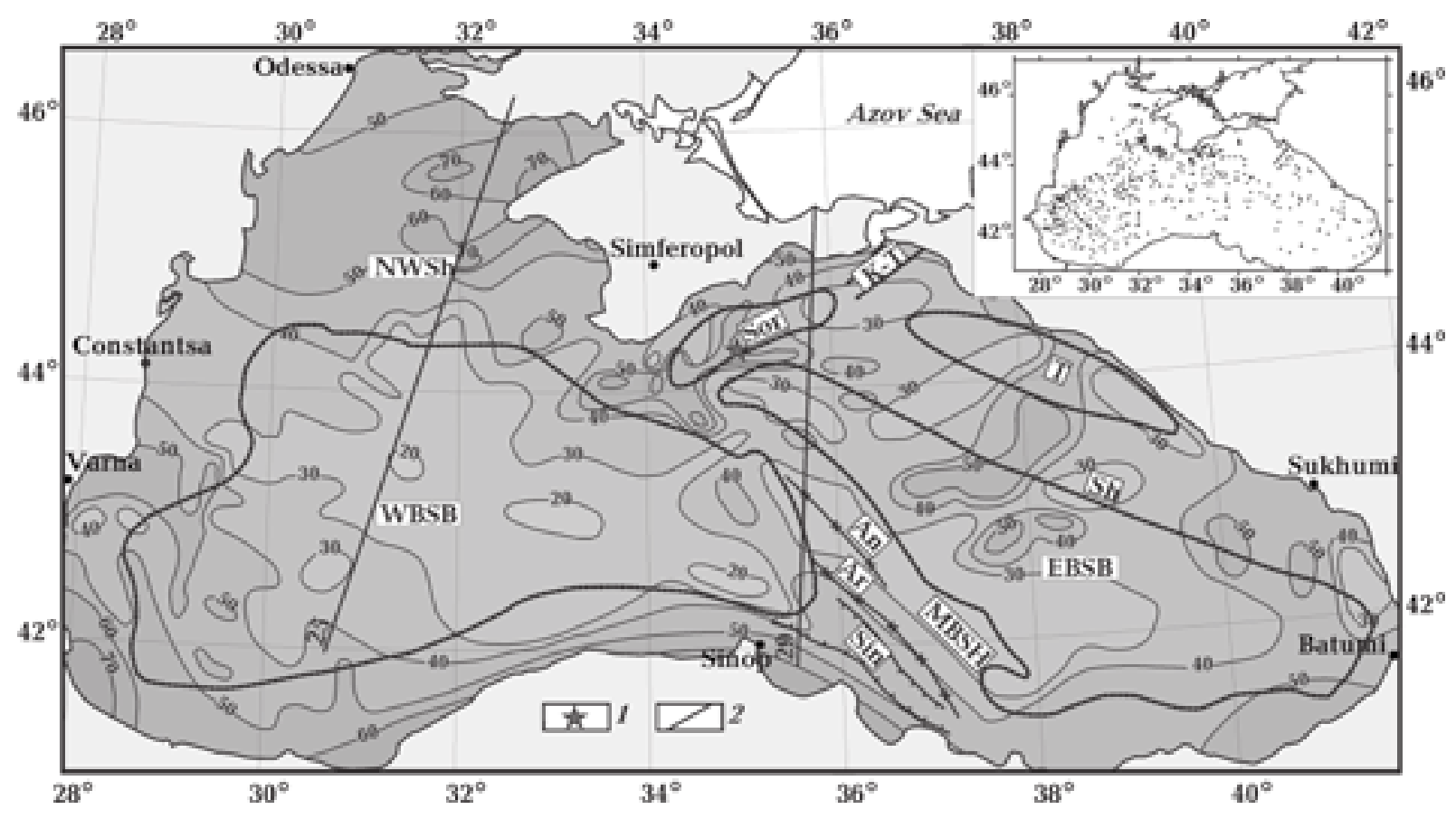

Fig. 4. Heat flow map. Units are in $\mathrm{mWm}^{-2}$. Inset shows location of heat flow stations: 1 - Dvurechensky mud volcano, 2 - DSS profiles. For other symbols and abbreviations see Fig. 1, 2. 
its development was initiated on the continental lithosphere of the terrains assemblage by rifting event in Cretaceous time. On the other hand, heat is transferred by conduction in the rigid lithosphere. Therefore, a geothermal model for the Black Sea lithosphere was elaborated by solving the non-stationary problem for layer of moving upper boundary [Kutas et al., 1989; Kutas, 2003; Galuskin et al., 2006]. Calculations have been performed mainly by applying analytical or numeral solutions of a thermal conductivity equation [Carslaw, Jaeger, 1959].

Thermal modeling involves multiple steps: calculating initial distribution of temperature, estimating degree of lithospheric stretching, adopting lithospheric structure and constructing distribution for thermophysical parameters and radiogenic heat generation [Kutas et al., 1989; Kutas, 2003; Galushkin et al., 2006]. Heterogeneous structure of lithosphere was approximated by layer-block features because it makes possible lateral variations in physical parameters and composition to be presented as individual blocks. Their changes with depth within individual blocks are taken as sets of layers of constant mean values of thermal conductivity and radiogenic thermal generation.

In developing models for distribution of thermal conductivity and heat generation in the sedimentary cover we used experimental data that were obtained mainly from the deep boreholes on the shelf and adjacent land areas. Deeper horizons were characterized by generalized data and correlative relationships between thermal parameters and seismic velocities [Rybach, Buntebarth, 1982; Kutas et al., 1989; Čermak et al., 1990; Rybach, 1996].

A lower boundary of calculations was limited by the $1300^{\circ} \mathrm{C}$ isotherm. The mantle heat flow was used as a boundary condition at the bottom. The value of initial rifting stage was assumed $90 \mathrm{mWm}^{-2}$, which corresponds to the present-day mean level for continental rifts [Sclater et al., 1980]. The measured flows of sub-bottom layers can be used for optimization in calculating mantle heat flow.

3.4. Seismic results. Seismic data from the Black Sea are briefly presented in this paper because the most essential results are described in full detail by [Starostenko et al., 2004a,b]. Here results are updated because new seismic information has been obtained since that time [Slishinsky et al., 2007; Khriachtchevskaia et al., 2009; Scott et al., 2009; Scott, 2009; Yegorova et al., 2010, 2013; Piip, Ermakov, 2011; Stovba et al., 2013; Graham et al., 2013]. All these data were used to constrain parameters of the sedimentary cover in gravity modeling.
In general, three main sedimentary layers are seismically mapped.

1. Sub-horizontal layer of the upper MiocenePliocene-Quaternary age, 1-2 km thick, uniformly covering the whole floor area of the Black Sea. It consists of interbedded sandy-clayey sediments with velocity $1-2 \mathrm{~km} / \mathrm{s}$.

2. Oligocene-Lower Miocene carbonaceous and clayey (Maikop series) deposits with a thickness of 3-5 km and velocity of more than $3 \mathrm{~km} / \mathrm{s}$ are widely spread in the deeper parts of the Black Sea. They usually thin out on the periphery of the basin.

3 . The oldest sedimentary layer is mainly composed of Paleocene-Eocene sediments $(2-8 \mathrm{~km}$ thick). They are characterized by velocity of $4.2-$ $4.5 \mathrm{~km} / \mathrm{s}$. Jurassic Cretaceous carbonaceous deposits occur throughout the sequence. The thickness of the oldest layer is proposed to be up to $6 \mathrm{~km}$, with velocity being ca. $5 \mathrm{~km} / \mathrm{s}$.

The thickest sediments are mapped in the central parts of the WBSB $(17 \mathrm{~km})$ and EBSB $(12 \mathrm{~km})$. A minimum thickness of sediments $(2.5 \mathrm{~km})$ has been documented above the An, Ar and Sh Ridges.

Newly formed oceanic crust or considerable thinned pre-Cretaceous is supposed to underlay the sedimentary layer. A «non-granitic» crustal layer was mapped in the WBSB and EBSB. The crystalline crust here has a minimal thickness of up to $5-6 \mathrm{~km}$. In the deeper parts of the basins the crust-mantle boundary mainly occurs at a depth of $20-25 \mathrm{~km}$.

4. Results and discussion. 4.1. Gravity effects of the mantle. To obtain the residual gravity effect of the crystalline crust for studying its fault tectonics one needs to remove the gravity effects of different layers, including mantle. The mantle gravity component has been first estimated with an empirical relationship between density and $P$ wave velocity. This approach allows us to characterize adequately the density distribution using a map of seismic tomography velocity $\left(V_{P}\right)$ for the Black Sea [Bugaenko et al., 2008].

A procedure of calculating $\rho=f\left(V_{P}\right)$ was as follows. Based on density and velocity values at 9 levels (a depth of 24 to $220 \mathrm{~km}$ ) from the Preliminary Reference Earth model [Dziewonsky, Anderson, 1981], a velocity/density relation was derived for the upper mantle using by least square technique [Wolberg, 2005]:

$$
\rho=0,176 V_{P}+1.955 \text {, }
$$

where $\rho$ - density $\left(\mathrm{gcm}^{-3}\right), V_{P}$ - velocity $(\mathrm{km} / \mathrm{s})$ of seismic waves. The least squares fitting to the 
original data is superb quality because the correlation coefficient $\left(R^{2}\right)$ is equal to 0.995 .

Applying the relationship (1), the values of density were calculated for each 7 slices of every $25 \mathrm{~km}$ interval from 50 to $200 \mathrm{~km}$ where seismic tomography velocity was determined in the Black Sea [Bugaenko et al., 2008]. To reduce calculated anomalies to a single reference system [Starostenko et al., 2004a] the density contrasts of these intervals were produced relative to the density versus depth plot of a Precambrian craton [Buryanov et al., 1981]. After the gravity effect of each 5 layers was calculated. Finally, they were summarized to obtain the total gravity effect of the layer from $50-200 \mathrm{~km}$ depth. The values of the total effect vary from +20 to $-45 \mathrm{mGal}$ (Fig. 5). Although the mantle component is poorly differentiated, it is distinctive in the WBSB and EBSB. The western basin is characterized by decrease in gradient values from the south to the north. The occurrence of relative positive and negative anomalies is characteristic of the eastern basin. The trend of the transitional zone between positive and negative values of the mantle component follows the configuration of the Pontides. The largest anomaly ( $45 \mathrm{mGal}$ ) occupies the southern part of the sea. The NW isolines of the mantle component clearly correspond to the strike of the high gradient zone in T-MAGSAT anomaly field. There are
NE axes of weak intensity horizontal gradient in the Western Black Sea.

\subsection{Density vs. depth plot for the sedimentary}

cover. To improve reliability of modeling infill its density was at first derived from density vs. depth conversion specially developed for the Black Sea. In general, density of sedimentary rocks is verified by some basic factors such as lithological composition, facial changes, burial history, occurrence depth, lithification and diagenesis. As they influence differently this parameter at the same depths on a regional scale, a generalized change in density with depth is necessarily to be determined using borehole and seismic data. It is common and efficient practice to use such a function as a model for the density distribution over a considerable spatial area.

This information is available from 17 wells of $3.5 \mathrm{~km}$ thick sedimentary sequence on the NW shelf of the Black Sea. It was used to reveal a density change with depth [Starostenko et al., 2005].

In contrast, density values of sedimentary rocks are practically unavailable in the deep-water basins of the Black Sea. Laboratory measurements were only performed on the samples from the youngest sediments of Pliocene - Quaternary age [Ross, 1978]. In this case, it remains only to apply velocity/density relationship using seismic data from the study area. Two such conversions

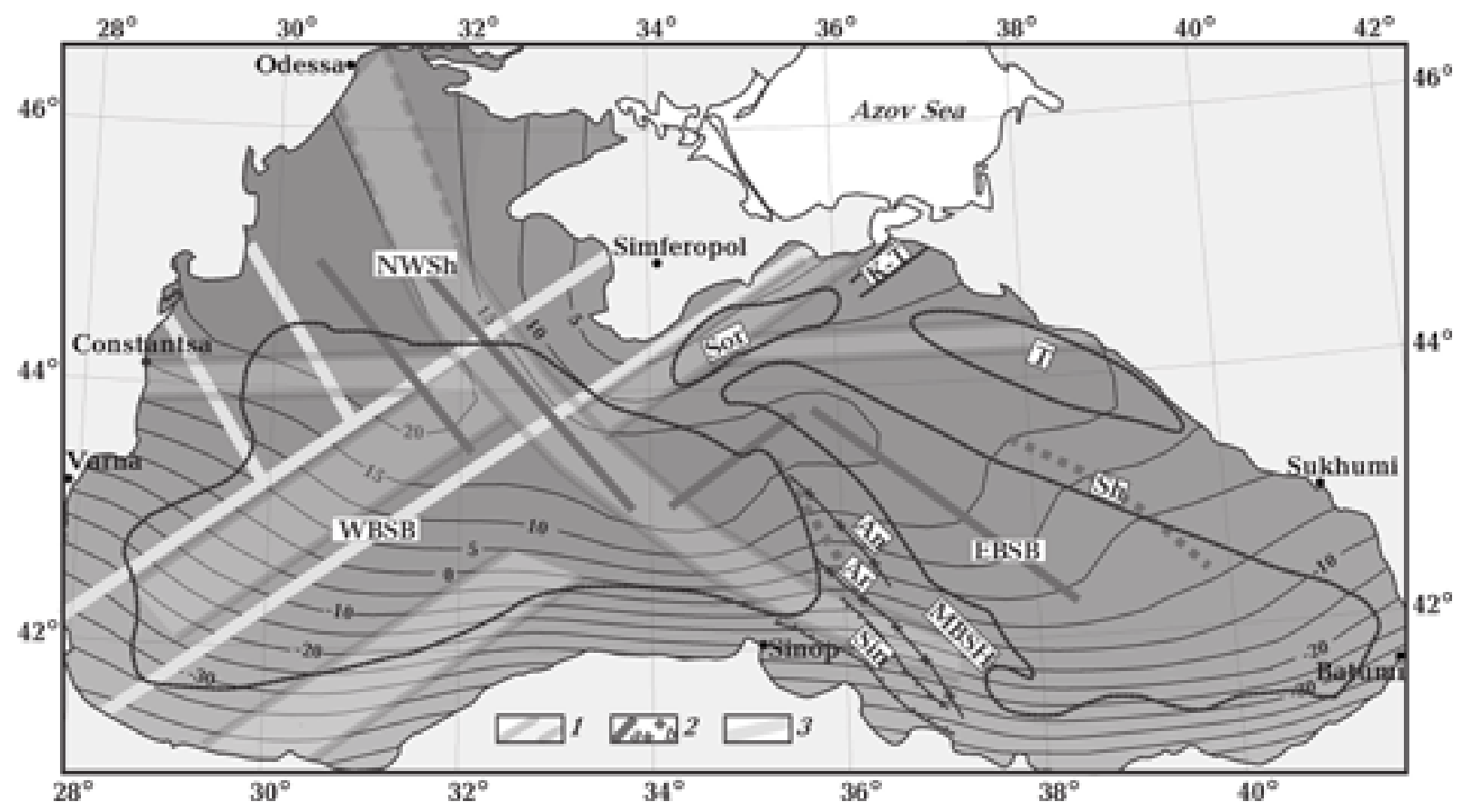

Fig. 5. The gravity effect of the mantle [Modified from Starostenko et al., 2010]. Units are in mGal. 1 - disturbances of the gravity mantle component, 2 - relative maximums $(a)$ and minimums $(b), 3$ - steep gradient of MAGSAT magnetic field. For other symbols and abbreviations see Fig. 1, 2. 
were developed by independent approaches for the Black Sea region [Balavadze et al., 1975; Pivovarov, Logvin, 2001]. The first of them started from studying 1400 samples from boreholes of the Western Georgia and Kuban-Stavropol region (Russia). It yielded the empirical relationship:

$$
\rho=1.8822-0.0871 V_{P}+0.1104 V_{P}{ }^{2}-0.0312 V_{P}{ }^{3} \text { ， }
$$

( $\rho$ in $\mathrm{gcm}^{-3}, V_{P}$ in $\mathrm{km} / \mathrm{s}$ for all formulae).

The second conversion was derived from interactive fitting an interdisciplinary seismic-gravity model along multichannel seismic reflection and deep seismic sounding profiles in the Azov Sea and central part of the East Black Sea (Profile 28/29). This has resulted in empirical equations:

$$
\begin{aligned}
& \rho=1.64+0.189 V_{P} \text { for }(2-10) \mathrm{km}, \\
& \rho=1.58+0.207 V_{P} \text { for }(10-40) \mathrm{km} .
\end{aligned}
$$

To test these relationships we use those of [Gardner et al., 1974] and [Brocher, 2005]:

$$
\begin{gathered}
\rho=1.74 V_{P}^{0.25}, \\
\rho=1.6612 V_{P}-0.4712 V_{P}^{2}{ }^{2} \\
+0.0671 V_{P}^{3}-0.0043 V_{P}^{4}+0.000106 V_{P}^{5} .
\end{gathered}
$$

The comparison is intended to know whether four dependences are not in conflict with each other. They are graphically presented in Fig. 6, $a$. It is seen that a maximum difference between density values for the same velocity from 4 plots does not exceed $0.06 \mathrm{gcm}^{-3}$. As the parameters of $\rho=f\left(V_{P}\right)$ functions are validly selected, they were averaged to obtain a generalized $\rho=f\left(V_{P}\right)$ plot (Fig. $\left.6, b\right)$ as

$$
\rho=1.3863+0.3554 V_{P}-0.0236 V_{P}^{2}\left(R^{2}=0.995\right) .
$$

Finally, a new empirical density vs. depth relation was compiled from the vertical velocity distribution in the sedimentary cover [Scott, 2009; Kozlenko et al., 2009; Yegorova et al., 2010; Piip, Ermakov, 2011]:

$$
\rho=1.8095+0.0954 H-0.003 H^{2}\left(R^{2}=0.992\right) .
$$

Fig. 6, $c$ shows the plot based on this relationship. In the deepwater basins the oldest succession is composed of Jurassic carbonaceous rocks. Its density is predicted from this plot to be $2.57 \mathrm{gcm}^{-3}$. However, this relatively high density is within a parameter range for such a rock type [Mavko et al., 2009]. In particular, the Cenomanian carbonaceous formation from the Babadag Basin on the Romanian coast and Cretaceous limestones from the boreholes on the NW shelf of the Black Sea have a density of 2.65 and $2.68 \mathrm{gcm}^{-3}$ respectively [Makarenko, 1997; Dimitriu et al., 2000].

4.3. Gravity effect of the crystalline crust. The residual gravity effect of the crystalline crust was obtained by removing gravity effects of water and sedimentary layers and mantle component from the observed gravity field (Fig. 7). It is of importance because only its specific characteristics reflect the density distribution and tectonic elements of this layer. The gravity effect of the crystalline crust is negative because density contrasts of the water and sedimentary layers are obtained relative to the mantle density [Starostenko et al., 2004a]. It changes from -720 to $-260 \mathrm{mGal}$. The tectonic elements can be ranged according to their gravity effects in the following order: the depressions - Western Black Sea (-260 mGal), Eastern Black Sea (-300 mGal), T Trough (-320 mGal), Sor Trough (-380 mGal); uplifts - MBSH (-440 mGal), Sh Ridge (from -460 to $-560 \mathrm{mGal}$ ). Values of the gravity effect vary along the shelf. Maximum va-
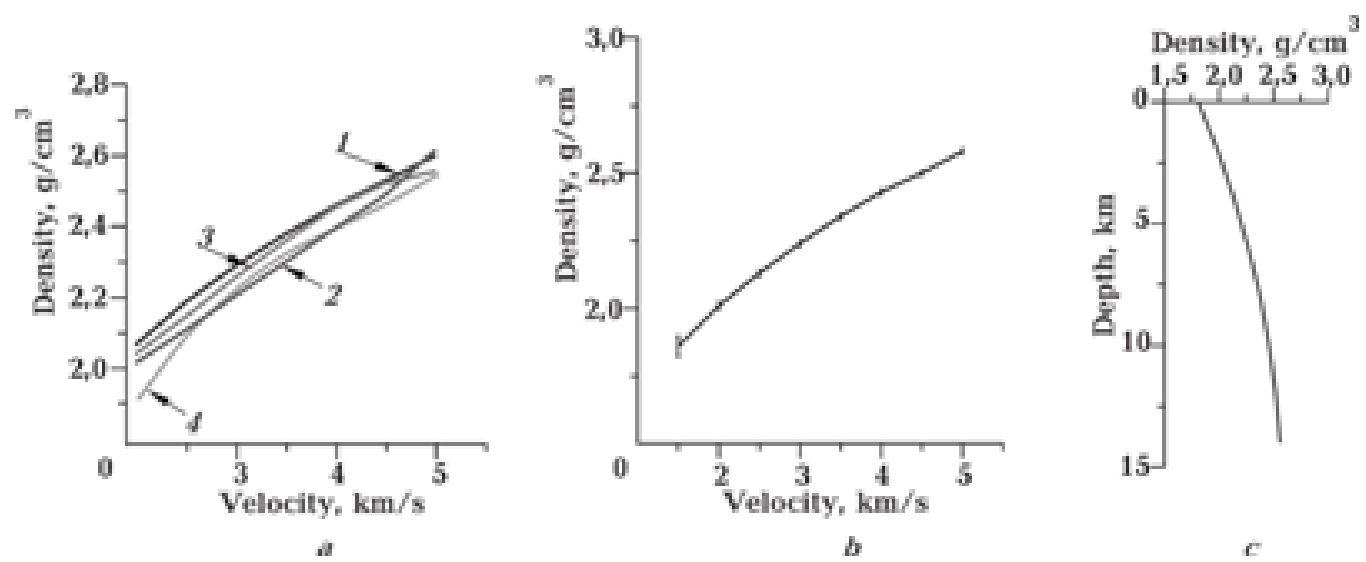

Fig. 6. Velocity/density plots (a): 1 - [Balavadze et al., 1975], 2 - [Pivovarov, Logvin, 2001], 3 - [Gardner et al., 1974], 4 [Brocher, 2005]; $b$ - averaged velocity/density plot derived from $(a), c-$ and density/depth plot. 


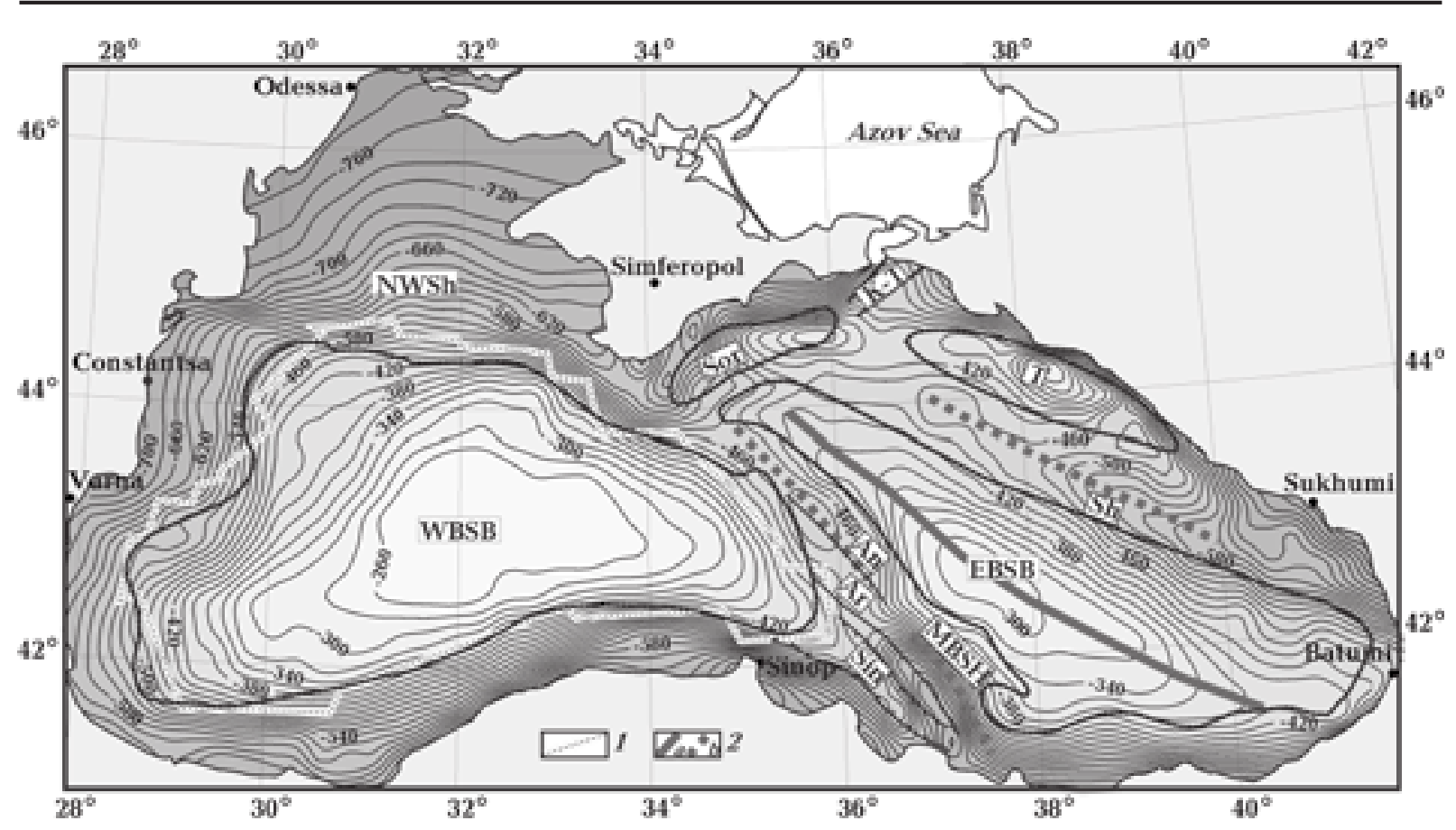

Fig. 7. The residual gravity effect of the crystalline crust [Modified from Starostenko et al., 2010]. Units are in mGal. It is obtained by removing the gravity effects of the water, sedimentary layers and Moho relief from the observed gravity field: 1 configuration of the WBSB is from residual gravity field, 2 - relative maximum $(a)$ and minimum $(b)$. For other symbols and abbreviations see Fig. 1, 2.

lues are recorded to the east of the T Trough and to the north of the Pon.

Each tectonic element is manifested by relatively low or high on the negative background in the gravity signature. In contrast to the observed field, which everywhere reflects clearly the sedimentary features, the crustal residuals mark depressions only by relative maxima whereas uplifts are recognized by relative minima. The WBSB and EBSB are characterized by relative maxima of +120 to +260 and +160 mGal respectively. The Sor Trough is marked by NE and EW trends of the gravity anomalies whose relative value is up to $+80 \mathrm{mGal}$. The $\mathrm{T}$ Trough is portrayed by two relative highs. The intensity of the SF maximum is $100 \mathrm{mGal}$ and the NW maximum is only $20 \mathrm{mGal}$. The axis of the Sin Trough coincides with that of the relative maximum of up to $100 \mathrm{mGal}$. The Sh Ridge are characterized by relative lows ranging from -40 to -100 mGal.

A clear correlation exists between the highs of the mantle component (see Fig. 5) and those of the gravity residuals (see Fig. 7) in the Eastern Black Sea as well as lows of these fields over the Shatsky Ridge and the MBSH. In contrast, such linear anomalies are not recognized in the WBSB.

4.4. Thermal model for the crust. Based on in- formation about crystalline crustal thickness, sedimentary stratigraphy, sedimentation rates, physical parameters of rocks and heat flow values, 2D thermal lithospheric models were developed along 25 and 29 DSS profiles (Fig. 8, 9) [Kutas, 2010]. The profiles intersect submeridionally the land areas, shelf, WBSB and EBSB (see Fig. 4).

The modeling results demonstrate that thermal balance of mantle heat flow and crustal radiogenic heat in the lithosphere of the Black Sea drastically changed during its evolution. The present-day radiogenic contribution of sediments is $10-13$ and $7-8 \mathrm{mWm}^{-2}$ in the central parts of the WBSB and EBSB respectively. This is smaller by $3-5 \mathrm{mWm}^{-2}$ than a stationary value of $13-17 \mathrm{mWm}^{-2}$ because the present-day contribution of Quaternary sediments is practically equal to zero.

On the top boundary of the crystalline basement, present-day mean heat flow value is $40-$ $48 \mathrm{mWm}^{-2}$ in the WBSB and $46-50 \mathrm{mWm}^{-2}$ in the EBSB. The Moho discontinuity has heat flow of $41-45 \mathrm{mWm}^{-2}$ over the whole sea.

An analysis of influence of selecting initial parameters on modelling results demonstrates that deviation of calculated temperatures and heat flows from real ones can reach 8-10 \% for the Earth's crust. 


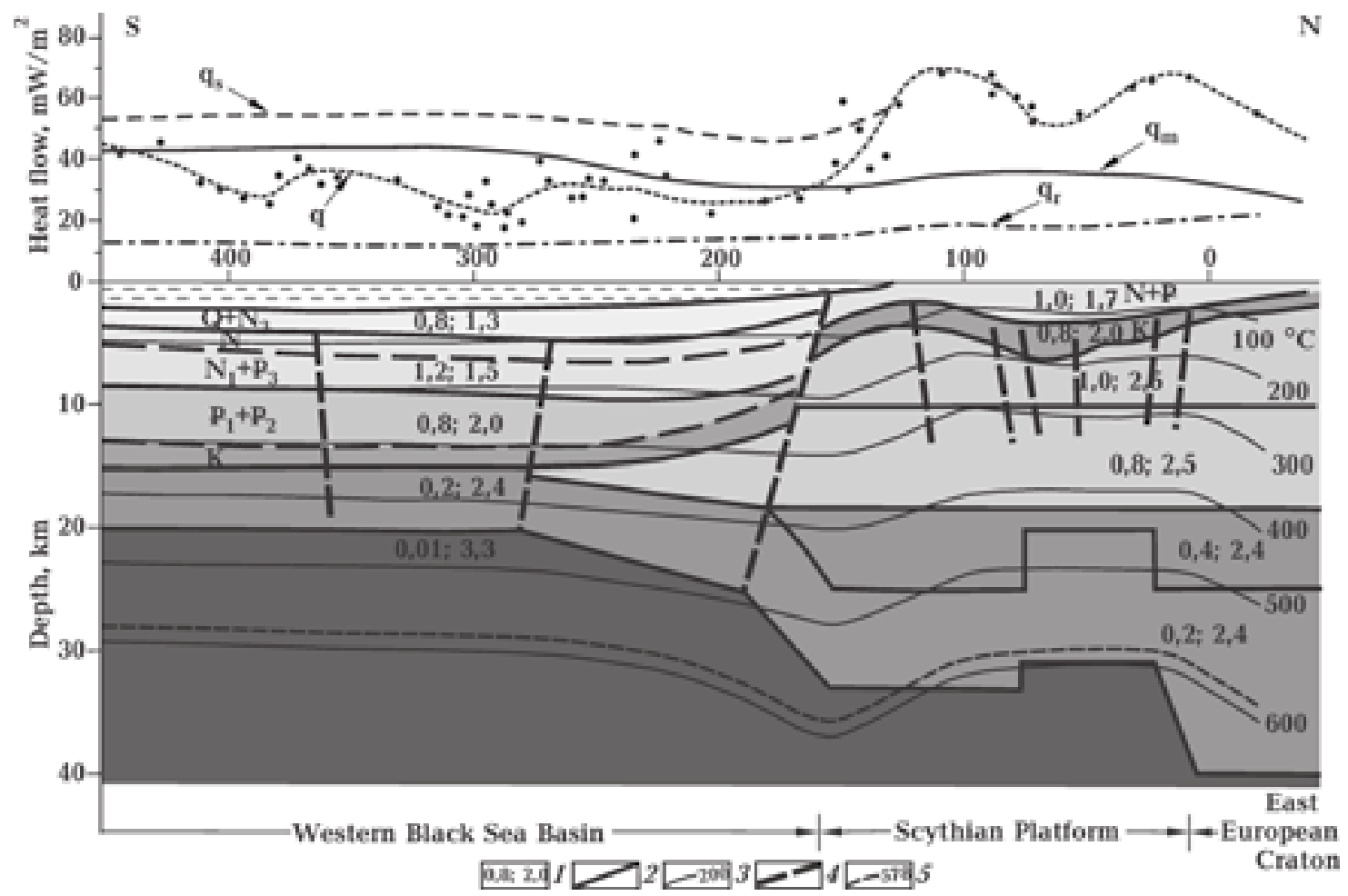

Fig. 8. Geothermal model for the crust along the 25 DSS profile [Kutas, 2010]. Heat flow: $q$ - determined, $q_{S}$ - trough sediments, $q_{m}$ - mantle, $q_{r}$ - radiogenic of the sedimentary layer, points denote measured heat flow values in $25 \mathrm{~km}$ corridors on both sides of the profile: 1 - radiogenic heat generation $\left(\mu \mathrm{W} \cdot \mathrm{M}^{-3}\right)$ and average value of thermal conductivity $\left(\mathrm{W} \cdot \mathrm{m}^{-1} \cdot \mathrm{K}\right), 2$ - boundaries of thermal layers, 3 - isotherms $\left({ }^{\circ} \mathrm{C}\right), 4$ - faults, 5 - magnetite Curie isotherm $\left(578^{\circ} \mathrm{C}\right)$.

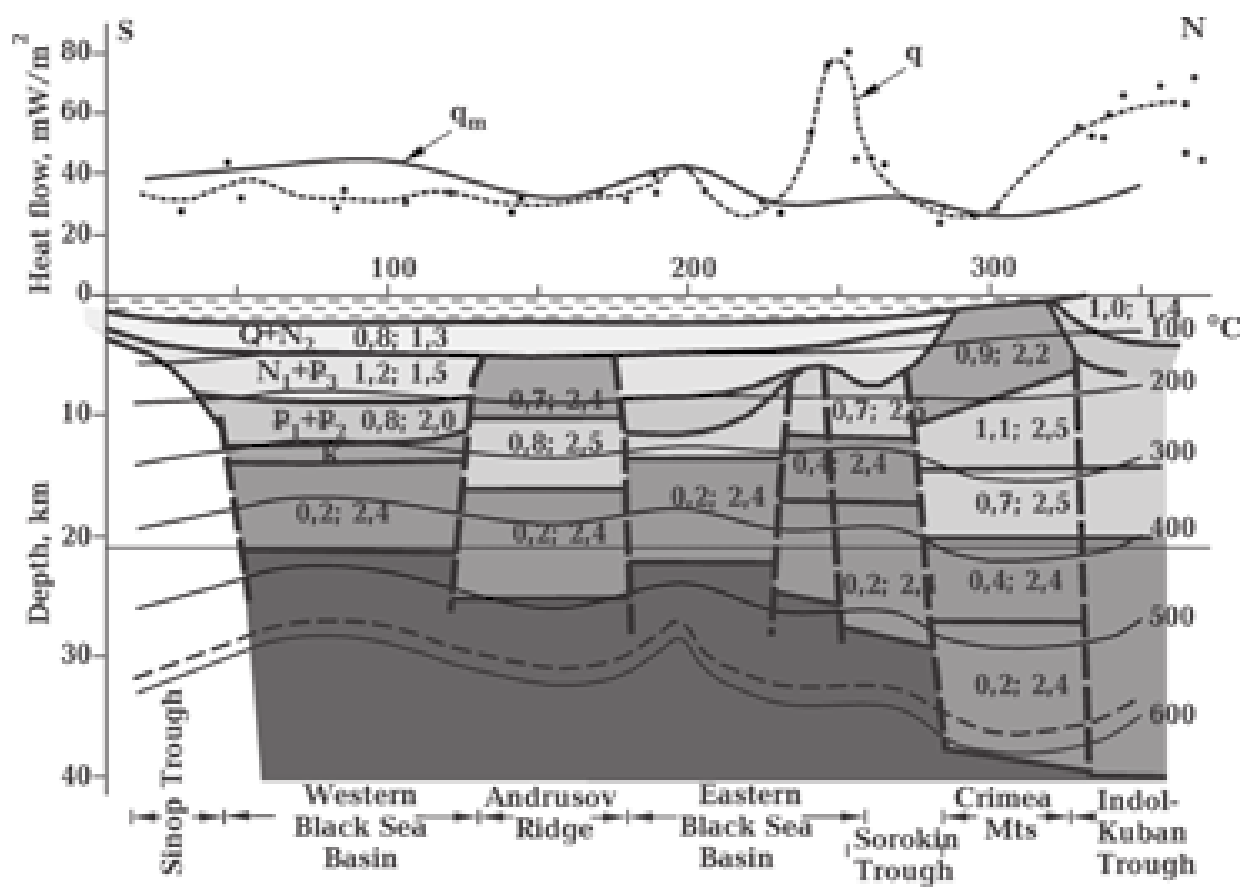

Fig. 9. Geothermal model for the crust along the 29 DSS profile [Kutas, 2010]. For captions see Fig. 8. 
Along the DSS profile 25 the mantle component varies between $45 \mathrm{mWm}^{-2}$ in the deep Black Sea basin and $20 \mathrm{mWm}^{-2}$ on the Precambrian EEC. If the latter value is supposed as the background level the anomalous heat flow in the deep-water parts of the west and east basin will be $20-25 \mathrm{mWm}^{-2}$.

Considerable variations in heat flow and thermophysical parameters along the profiles result in great changes of temperature in the crust and upper mantle. In the Black Sea the $100^{\circ} \mathrm{C}$ isotherm occurs at $2.0-2.5 \mathrm{~km}$ depth. Beneath the edge of the ancient platform it plunges to $4 \mathrm{~km}$. At the depth of $10 \mathrm{~km}$ the temperature is $250-290{ }^{\circ} \mathrm{C}$ and $180^{\circ} \mathrm{C}$ in the sedimentary cover and beneath the ancient platform respectively. The $30 \mathrm{~km}$ slice is characterized by $560-620^{\circ} \mathrm{C}$ below the deepwater areas and $400-430{ }^{\circ} \mathrm{C}$ in the ancient platform. The asthenosphere top of $1300{ }^{\circ} \mathrm{C}$ [Wyllie, 1979] occurs at $70-90 \mathrm{~km}$ in the Black Sea. It is not recognized at a depth of $200 \mathrm{~km}$ below the ancient platform. Similar distributions of the heat flows and temperature are observed along the 29 DSS profile in the EBSB.

The present-day low heat flow values in the near bottom layers of the Black Sea (mean value $<40 \mathrm{mWm}^{-2}$ ) do not reflect the real thermal regime in the lithosphere due to climate changes and strong thermal blanketing effect from postEocene sedimentary layers. After correcting for those factors heat flow increases to $55-60 \mathrm{mWm}^{-2}$ at a depth of 3-5 km [Kutas, 2003] compared with mean surface value of $35-40 \mathrm{mWm}^{-2}$ for the EEC. In opposite to the opinion of resemblance of the Black Sea lithosphere to that of the EEC [Yegorova et al., 2013], the upper mantle beneath the Black Sea is characterized by high thermodynamic activity as demonstrated above. Such a high activity in the Black Sea gives strong evidence for its rift origin and young geothermal processes.

Four observations support diachronous opening of the two Black Sea sub-basins. They are the following: 1) practically the same level of mean surface heat flow in them despite significant differences in overall sedimentary thickness; 2) in the western Black Sea, heat flow is relatively uniform within deep-water parts whereas in the eastern Black Sea it is much more differentiated in the same areas; 3) two regional perpendicular trends in heat flow anomalies in the sub-basins; 4) heat flow pattern in the western Black Sea is not consistent with that of the adjacent continental tectonic elements while in the eastern Black Sea regional picture of heat flow anomalies is in agreement with that one of tectonic features on land. Ca. $40 \mathrm{Ma}$ interval is estimated to be necessary between the opening events, with the western basin being rifted earlier in the Albian-Cenomanian time [Kutas, 2003].

\subsection{D Magnetic model of the crystalline crust.}

Fig. 10 (see p. 7) presents the 3D magnetic model for the crystalline crust of the Black Sea as projections of large deep causative bodies onto the seafloor. Magnetic sources are unevenly distributed and are mostly associated with the major tectonic units, deep faults and density distribution in the mantle. Magnetic sources are often complicated by narrow linear magnetic bodies with strikes conformable with general trend. However, their specific individual effects were not calculated at a regional scale due to resolving capability of modeling.

Magnetic intensity is within broad range from near 0 to $3.5 \mathrm{~A} / \mathrm{m}$. The most intensive magnetization is characteristic of the northwestern shelf while mainly the nonmagnetic crust is recognized in the southern domains of both sub-basins and over the MBSH and to the north-west of it.

A spatial pattern of magnetic bodies is mostly controlled by long living OSO mantle fault zone that divides the Black Sea into western and eastern basins. This zone itself is traced by a steep gradient of the mantle gravity component. It separates the magnetic crust of the western Odessa shelf from the practical nonmagnetic crust in the eastern one. The only exception is the NE Karkinit Trough where a strongly magnetized block occurs. Crustal magnetization ranges from 0.75 to $3.5 \mathrm{~A} / \mathrm{m}$ on the northwestern continental slope, with strongest intensity being associated with the southeastern Odessa anomaly traced from the Ukrainian Shield.

The southern boundary of this magnetic domain coincides with the latitudinal zone of the crystalline crust and the belt of increased gradients in the mantle gravity component, although southeastern boundaries of separate sources have a northeastern striking. The main feature in spatial distribution of magnetic bodies in the Black Sea is their concentration as large zones $30-100 \mathrm{~km}$ wide whose structure is rather complex. The zones are characterized by NE and NW trends in the western and eastern sub-basins respectively, whereas in the OS fault they are distinguished by NW varying direction. Magnetic crustal bodies control the Western Black Sea zone of the deep faults in the WBSB. The crystalline crust in the EBSB is mostly nonmagnetic.

However, on its background there are two narrow linear magnetic dyke-type bodies of NW striking. Only in the northwestern part of the basin the segment of crustal magnetization of up to $1.5 \mathrm{~A} / \mathrm{m}$ occurs clearly delineating its southwest- 
ern boundary. High magnetization intensity (up to $2.5 \mathrm{~A} / \mathrm{m}$ ) is of characteristic for the magnetic sources beneath Shatsky Ridge. Both anomalous domains are bounded by the EW zone of steep gradients of the mantle gravity component. It follows that large areas of the magnetic crust is also delineated by the faults of the mantle origin. Only one body to the northwest of this zone below the SW Sor Trough reflects the dominant NW trend.

In summary, there are three regional magnetic zones in the crystalline crust of the WBSB and EBSB to be crucial for geotectonic implication (see section 4.6). These are oblique source zones WBS and $\mathrm{AB}$ fault zones in sub-basins, which can be interpreted as indicators of stretched (rift) zones. The third non-conformable zone is the set of causative bodies of the OS fault, zone which is considered to be a suture.

4.6. Fault tectonics of the crystalline crust. An integrated analysis of the observed magnetic field (see Fig. 3), residual gravity field (see Fig. 7), mantle gravity component (see Fig. 5) and seismic tomographic results [Bugaenko et al., 2008] allowed us not only to study fault tectonics of the crystalline crust but to estimate depth penetration of the faults.

Fig. 3 and 7 demonstrate that most number of faults can be attributed to the crystalline crust because they are distinguished in the magnetic and residual gravity fields (Fig. 11). The largest high gradient zones of the T- and Z-MAGSAT anomaly fields [Coles et al., 1982; Haines, 1985] and the zones of disturbances of the mantle gravity component that are also shown in this figure. These zones indicate the general strikes of the major faults systems and can be the evidence for deep origin of the large faults related to them.

There are two major faults system in the Black Sea. The diagonal system of the faults (NE and NW strikes) controls its major tectonic units. The NW $\left(120-140^{\circ}\right)$ faults are characteristic of the eastern Black Sea while NE faults are observed in its western part. The diagonal system includes the Alushta-Batumi (AB) faults zone and the WBS fault zone subparallel to the Intra-Pontide Suture whose age is the Early Cretaceous [Akbayram et al., 2009]. The strike of both these zones coincides with that of the SE Balkanides fault. The large OS fault zone of varying strike $\left(145-100^{\circ}\right)$ also belongs to the diagonal system with occupying a specific position.

The faults of the Western Black Sea (WBS) fault zone associated with linear magnetic anomalies and transverse "transform" faults can be interpreted to be of spreading origin by analogy with the spreading nature of the $\mathrm{AB}$ anomaly as was proposed by [Shreider et al., 1997]. The NE strike of the diagonal faults system is consistent with that of the southern and southwestern EEC boundary. The geometry of the Crimean Peninsula coastline is controlled by the faults of this system [Chekunov, 1994]. The faults of the diagonal system govern also the distribution of heat flow anomalies in the western sub-basin whilst the complex pattern of the $\mathrm{AB}$ zone correlates with the heat flow fabric in the eastern sub-basin (see Fig. 1, 4).

Based on the interpretation of the potential fields, OS fault zone was extended southeastward into the Ordu offshore. As a result, a new deep tectonic disturbance was first delineated in the Black Sea, which was termed as OSO fault zone.

The dextral OSO fault zone runs from the EEC across the Black Sea to the Pontides. Our data, particularly magnetic modeling, show that it is a zone with a variable width (up to about $100 \mathrm{~km}$ ) consisting of the fragments with the same strike which are often displaced by orthogonal faults. This zone bounds the eastern branch of the WBS fault zone. However, the NE faults are delineated further to the northeast and can be considered as sinistral slip-faults.

The OS zone consists of the faults of the same trend in the WBSB and beneath the An and Ar Ridges. On the Odessa shelf the uppermost eastern member of the OS zone coincides with the so called the West Crimean (WC) fault [Finetti et al., 1988]. Although the WC fault is not seismically documented in the deep-sea area it is postulated that this fault plays a crucial role in opening the WBSB [Okay et al., 1994]. However, in this paper its continuation to the western sub-basin was inferred from multidisciplinary analysis as the dextral slip-fault on the MBSH displacing the An Ridge relative to the Ar Ridge to the northwestern direction.

The northern linear segment with strike $145^{\circ}$ is traced by the uppermost western fault to the Sinop meridian (OS zone itself). The southern fragment is arc-like (130-100 strike). One can suppose that OSO zone itself occurs in the form of set of dextral displacement and continues on the Sinop offshore as the fault separating the Upper Cretaceous volcanic arc of the Central and Eastern Pon. The circular OSO southeastern offset results from general dextral shift along the OSO zone parallel to the Middle Alpine thrust belt bounded the Eastern Pon on the north [Nikishin et al., 2003]. In whole, the OSO zone follows the strike of the North Anatolian Fault [Rangin et al., 2002] and the NA thrust front [Finetti et al., 1988] and is consis- 
tent with their dextral motions. In turn, the Neo thrust front extends on the direct continuation of the TTZ and its trend is clearly sub-parallel to that of faults in the crystalline crust of the Black Sea (e.g. the OSO fault zone). Moreover, to southwest of the Black Sea its strike is concordant with that of the Alpine features such as the Vardar Suture, Pelagonian Zone and NW part of the Hellenic Trench [Bozkurt et al., 2000]. The dextral slipfaults of the EEC boundary are delineated in the OS fault zone on the NW shelf and on the northern part of the WBSB.

The general strike of the WBS and the OS fault systems correlate well with those of steep gradient zones of the T-MAGSAT anomalies and the zones of disturbance in the mantle gravity component (see Fig. 5) that suggests that these zones are of a mantle origin. In turn, the zone of steep gradients of the T-MAGSAT anomalies with the northwestern trend corresponds to the southwestern continuation of the TTZ (see Fig. 1, 11, p. 8). The $\mathrm{AB}$ faults zone is associated with gradients of the mantle gravity component. The WBS fault zone is marked by weakly increased gradients of this component. The $\mathrm{AB}$ faults zone is mapped by the fragments of the NW variable strike distorted by $\mathrm{NE}$ «transform» offsets just as the linear magnetic anomalies within it. The central part of this zone is manifested by a weak minimum of the mantle component.

The orthogonal fault system is only fragmentary expressed in the geophysical fields. The latitudinal belt of its separate fragments can however be observed which are traced periodically in the northern area and are often accompanied by the magnetic minima and residual gravity maxima. This can be clearly visible in the mantle gravity component (see Fig. 5, 15, p. 8). Its intensity increases to the north of this zone. Moreover, in the eastern sub-basin the latitudinal zone is determined in the tomographic image up to a depth of $200 \mathrm{~km}$ [Bugaenko et al., 2008]. It is traced to an area east of the NE segments of the high gradients in the T-MAGSAT anomalies and gravity mantle gradients as well as to the west of the OS fault zone. North of the Pon suture zone, there exist successive shifts of the magnetic minima and conjugated maxima by dextral faults in the central part of the Pon.

The largest faults zones discussed and their associated systems are also characteristic of the Black Sea periphery. The present-day configuration of the WBSB boundaries seems to be formed by them. This is best exemplified by its northern and northwestern boundary. The northern bound- ary could be produced by the resulting influence delimitated by dextral slip faults and sub-latitudinal faults, which are clearly observed in the residual gravity field (see Fig. 7).

Comparing Fig. 11 and the major faults and tectonic elements of the Black Sea and adjacent land (see Fig. 1), one can draw a conclusion that faults of the crystalline crust in the Black sea are the continuations of that on land and shelf or have concordant trends with them. It is true, first of all, for the OS fault zone. As the northwestern fragment of the OS fault zone is clearly delineated within the Ukrainian Shield, its southern slope and northwestern shelf [Chekunov, 1987; Kravchenko et al., 2003], and is manifested in the gravity mantle component (see Fig. 5). The reliability of discerning the deep faults (see Fig. 11, p. 8) is fully confirmed by DSS results along profiles 25 and 26 (Fig. 12).

One can suppose that this fault zone is the oldest in origin in the Black Sea. It implies that the OS fault seems to be initiated in the Precambrian time and repeatedly reactivated later. According to a set of paleo-reconstructions of P. Ziegler [Ziegler, 1982] the strike of its northern OS portion coincides with that of major tectonic features in the Western and Central Europe at least since the Early Triassic time.

The $A B$ zone and the southeastern setoff of the OSO fault are not manifested themselves in the feature of the Pon and A-T zone being limited by Middle Alpine thrust front [Finetti et al., 1988; Rangin et al., 2002].

The diagonal system of the faults in the crystalline crust of the Black Sea mostly controls its opening and developing. Magnetic bodies, which are indicators of extension zones, in turn, relate to the main fault zones. In the WBS azimuths of extension zones are $145-325^{\circ}$ in suggesting its perpendicularity to the striking of magnetic bodies.

The northern and southeastern OSO extension fault zone is distinguished by $55^{\circ}, 235^{\circ}$ and $10^{\circ}$, $325^{\circ}$ strikes respectively. The trends in the northern $\mathrm{AB}$ zone are 30 and $210^{\circ}$, while in the southeastern portion are 50 and $230^{\circ}$. It implies that the magnetic sources in the large fault zones formed diachronously. L. Besutiu and D. Zugravesku came to the same conclusion [Besutiu, Zugravesku, 2004]. As the $\mathrm{AB}$ fault zone is not strictly perpendicular to the WBS fault zone and is not strictly parallel to the OSO zone with fragments of sinistral slip-faults, the WBSB rifted and opened later than the WBSB.

4.7. The Mid-Black Sea Height and the Sinop Trough. Although the MBSH in some geotectonic models plays a key role in opening the EBSB [e.g. Zonenshain, Le Pichon, 1986; Finetti et al., 1988; 

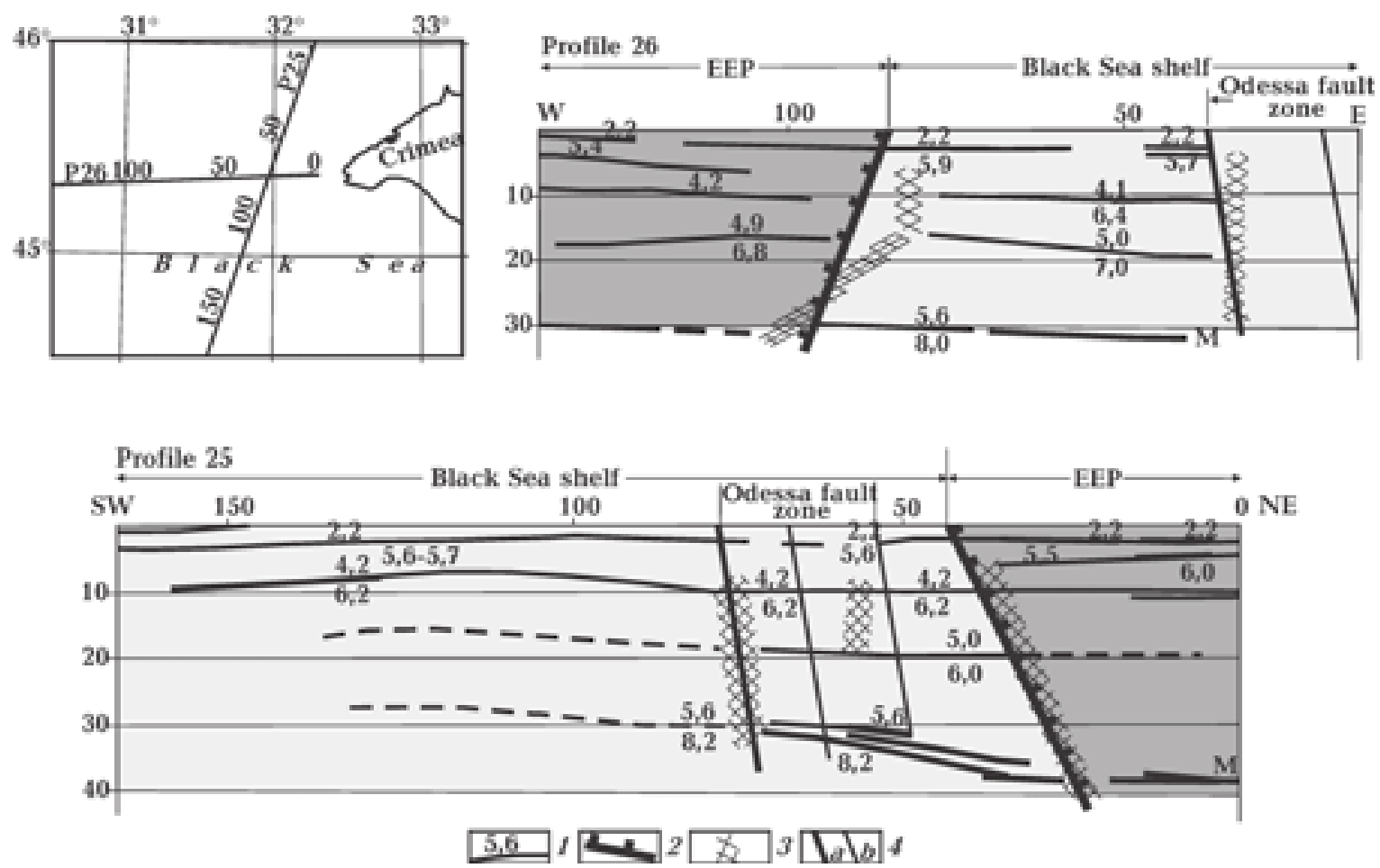

Fig. 12. Deep faults from DSS results [Bulanzhe et al., 1975] and this work: 1 - velocity, $\mathrm{km} / \mathrm{s}, 2$ - EEC boundary; 3 - faults are from DSS data; 4 - faults are from this work ( $a$ - the first order, $b$ - the second order).

Okay et al., 1994; Scott, 2009], information of a regional scale has been only obtained concerning structure of its crystalline crust. The Moho depth varies from 29 to $33 \mathrm{~km}$ along its strike length [Starostenko et al., 2004a; Yegorova et al., 2010]. Little attention is also given to the structure of the crystalline crust in the Sinop Trough whose base lies at $35-40 \mathrm{~km}$ from gravity modeling [Starostenko et al., 2004a]. To narrow this gap a detailed gravity modeling the geological cross-sections of the An and Ar Ridges and Sin Trough has been undertaken. Parameterization of density models is based on seismic data [Rangin et al., 2002; Slishinsky et al., 2007; Scott, 2009; Yegorova et al., 2010; Stovba et al., 2013] and density/velocity relationships [Christensen, Mooney, 1995; and see section 4.2].

In observed gravity field the Andrusov Ridge is manifested by negative values of $10-20 \mathrm{mGal}$ while they reach $-50 \mathrm{mGal}$ over the Arkhangelsky Ridge (Fig. 2, 13). Negative gravity anomalies over the MBSH are not unique phenomenon in the World Ocean. The same sign of the gravity field is registered over the buried $85^{\circ}$ Ridge in the Indian Ocean [e.g. Sreejith et al., 2011].

The anomalies of gravity residual field of up to -80 and $-260 \mathrm{mGal}$ are observed over the Andrusov and Arkhangelsky Ridges respectively (Fig. 13, 14). A weak gradient of the mantle gravity component is characteristic of both ridges. A pattern of the residual gravity field produced by the crystalline crust (see Fig. 7) allow us to continue the Arkhangelsky Ridge axis to the northwestern up to the boundary of the EBSB.

The Andrusov Ridge has a complex structure of the crystalline crust, which is bounded by faults with dike-like weak magnetic bodies (see Fig. 13). Later these faults were inherited by distortions in the sedimentary cover [Stovba et al., 2013].

Our density model is based on the most comprehensive velocity model for the crust of the northern An Ridge [Scott, 2009]. Density of crystalline layers was calculated using velocity/density relation [Christensen, Mooney, 1995]. Rock density $2.72 \mathrm{gcm}^{-3}$ corresponds to an unsorted mixture of sedimentary rocks and granitoids while density $2.75 \mathrm{gcm}^{-3}$ is characteristic of granodiorites [Harvey et al., 2005]. Seismic velocity is $7.8 \mathrm{~km} / \mathrm{s}$ at the base of the crystalline crust at the $24 \mathrm{~km}$ depth. Beneath it occurs a $8 \mathrm{~km}$ thick body on which lower edge seismic velocity decreases to $6.8 \mathrm{~km} / \mathrm{s}$.

The velocity in the body suggests that it is formed by basic-ultrabasic rocks. The magmatic body seems to result from rejuvenation of the faults within the OSO zone in the Jurassic time, which also produced weakly magnetized objects on its periphery. 

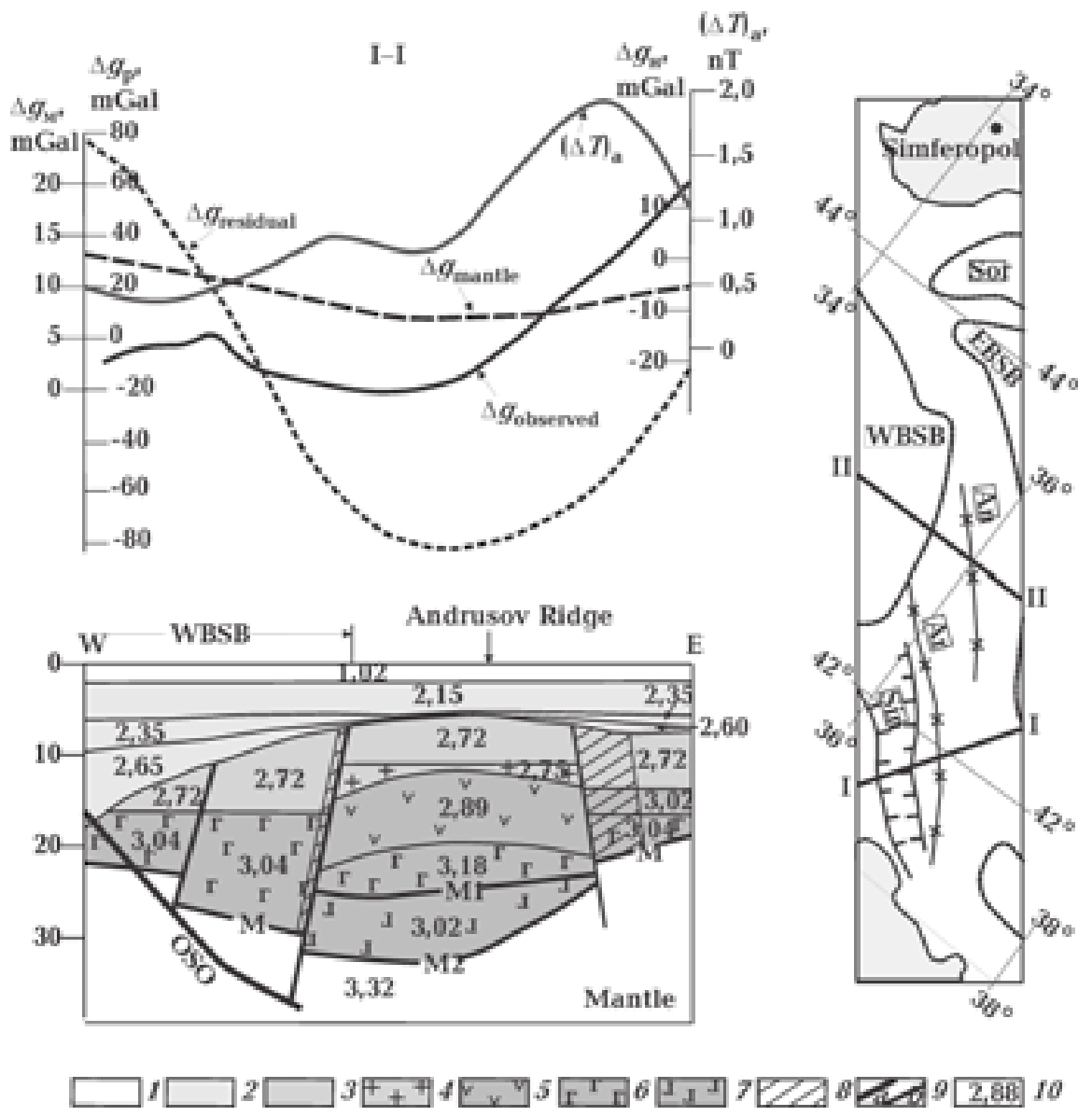

Fig. 13. Density model for the Andrusov Ridge, profile I-I: 1 - water, 2 - sediments, 3 - sedimentary rocks and granitoids, 4 - granodiorites of the upper crust, 5 - basic rocks, 6 - basic and ultrabasic rocks, 7 - magmatic body [Scott, 2009], 8 body of increased magnetization, 9 - OSO fault zone $(a)$, other faults $(b), 10$ - density is in $\mathrm{gcm}^{-3}$. For other symbols and abbreviations see Fig. 1.

On the other hand, 2D and 3D gravity modeling indicates that at a depth of $32 \mathrm{~km}$ density of the upper mantle is $3.30-3.32 \mathrm{gcm}^{-3}$ [Scott, 2009] and $3.32 \mathrm{gcm}^{-3}$ [Starostenko et al., 2004a]. Thus, seismic and gravity data reveal two Moho discontinuities $\left(\mathrm{M}_{1}\right.$ and $\left.\mathrm{M}_{2}\right)$. It implies a two-stage process in forming the Andrusov Ridge. The younger $\mathrm{M}_{2}$ discontinuity is asymmetrically sagged relative to the ridge axis and displaced to the WBSB. Sag of the $\mathrm{M}_{1}$ discontinuity has less amplitude although shifted to the southwest.

The Arkhangelsky Ridge is situated on slope of the Moho surface plunging in an echelon style from 28 to 32 to the southwest (see Fig. 14). Average density of the crystalline crust $2.93 \mathrm{gcm}^{-3}$ corresponds to basalt. To southwest from the ridge, the crustal thickness increases to $42 \mathrm{~km}$ and its density reaches the peak $3.02 \mathrm{gcm}^{-3}$ that is the characteristic of basic-ultrabasic rocks.

The Sinop Trough consists of material whose average density is estimated to be $3.02 \mathrm{gcm}^{-3}$. Such a value is commonly taken as equivalent of basic-ultrabasic rocks. This density feature extends to a depth of $24 \mathrm{~km}$ where it is truncated a branches of the OSO fault which gently dips to the northeast. As was mentioned previously the OSO fault zone reactivated repeatedly and acted as dextral slip-fault at the last stage of its evolution.

Newly obtained information on fault tectonics, density and velocity parameters of the crust and its transitional zone to the mantle reveals distinct pattern of forming and developing the Andrusov and Arkhangelsky Ridges. This is not surprising because the crust beneath the Andrusov Ridge is the stretched Precambrian continental one, and the Archangelsky Ridge is exclusively produced by basic - ultrabasic rocks produced by active volcanism in the Upper Cretaceous [Nikishin et al., 2013]. These two units moved with respect to one another by faults of the OSO zone. In other 

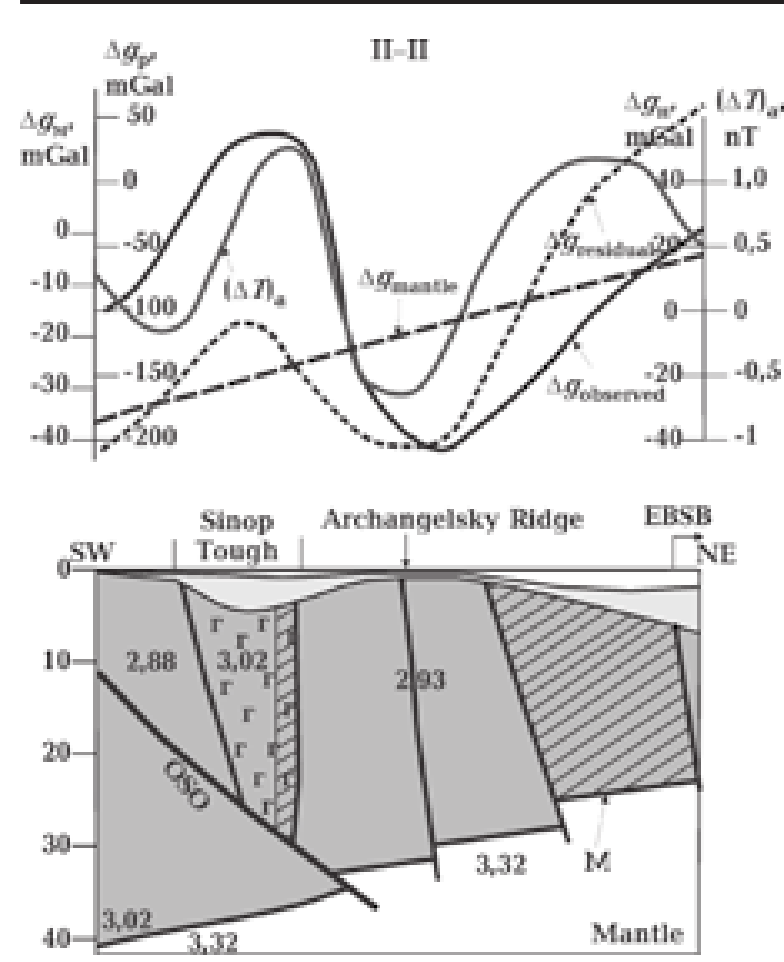

Fig. 14. Density model for the Arkhangelsky Ridge and Sinop Trough, profile II-II. For symbols and abbreviations see Fig. 1, 13.

words, despite common belief the MBSH is not a single tectonic feature because the Andrusov Ridge is underlain by stretched continental crust of the Precambrian age while the Arkhangelsky Ridge is composed of the thicken ocean crust of the Cretaceous in age. The formation of the Sinop Trough is due to the Late Miocene incipient dextral strike-slip motion of the North Anatolian Fault resulted from collision of the Anatolian microplate [Rangin et al., 2002].

4.8. The structure and geophysical heterogeneities of the crystalline crust and upper mantle. Fig. 15 and 16 present information on the relationship between the topography of the crustal base, gravity, magnetic, seismic and thermal characteristics of the crystalline crust and upper mantle. As is seen, the WBSB and EBSB are distinguished by the uplift of the Moho-discontinuity, occurrence of the "non-granitic» crust and magnetic heterogeneities whose distribution is controlled by the major faults zones.

Practically the whole WBSB has the «basaltic» crust. The areas of the increased magnetization of the "basaltic» crustal layer in the WBSB relate to the largest OSO and WBS fault zones. The crustal magnetization of the NW and NE parts of the WBSB is $1.0-3.0 \mathrm{~A} / \mathrm{m}$ as inferred from the 3D magnetic modeling [Sollogub, 1987; Pashkevich et al., 1993; Chekunov, 1994 and see section 4.5]. The domains of the increased magnetization coincide with the northern portion of the residual gravity maximum, occupying the slopes of the uplifts in the crustal base where temperature is $600^{\circ} \mathrm{C}$ on a depth of ca. 30 km. (see Fig. 8).

The causative sources of the T-MAGSAT Kursk anomaly whose southwestern part occupies the large segment of the EEC - Sarmatia and the northwestern Black Sea are characterized by mean magnetization intensity of $1.5 \mathrm{~A} / \mathrm{m}$ for the crust [Pashkevich et al., 1995; Taylor et al., 1995]. The southwestern edge of its source corresponds to the TTZ and its supposed southeastern continuation. The southeastern border of the causative body of the Kursk anomaly is parallel to the EEC margin.

The local magnetic anomalies are caused by sources with magnetic contrasts of $0.5-0.7 \mathrm{~A} / \mathrm{m}$. The regional and local magnetic sources relate to the lower («basaltic») crust. Depths to their lower «non-granitic» surfaces are not clearly determined although they do not exceed a depth to the M-discontinuity [Starostenko et al., 2004a]. The crust in the southern and western parts of the basin is nonmagnetic. In the EBSB the "non-granitic» crust is distinguished only in its central part. It clearly correlates with gravity residual highs, an axis of the weak mantle maximum the non-magnetic crust and a rise in the topography of the crustal base (see Fig. 10, p. 7; 15, p. 8). This basin is characterized by the NW strike of the magnetic anomalies (see Fig. 10, p.7; 15, p.8).

The crust in the western and northwestern areas of the EBSB is characterized by increased magnetization of up to $3.0 \mathrm{~A} / \mathrm{m}$ [Belousov et al., 1988]. Causative bodies continue outside the basin boundary following its configuration. The magnetization of local sources, which also are situated in the «basalt» layer, does not exceed $1.0 \mathrm{~A} / \mathrm{m}$ against the common background [Shreider et al., 1997].

In opinion of [Shreider et al., 1997] linear magnetic anomalies within the $A B$ faults zone seem to be related to the Cretaceous rift. If magnetic anomalies and the WBS faults zone of the NE strike are also associated with the rift, these systems of the magnetic anomalies differ not only in their strikes but also in their positions relative to the contours of the basins. The first system is mapped over the Shatsky Ridge and partly within the eastern part of the EBSB itself. The second system is documented in the NW part of the WBSB to the west of the OS fault zone.

Fig. 16 shows the heterogeneities of the crystalline crust and lithosphere as well as the thickness of the thermal lithosphere in the WBSB and EBSB. 

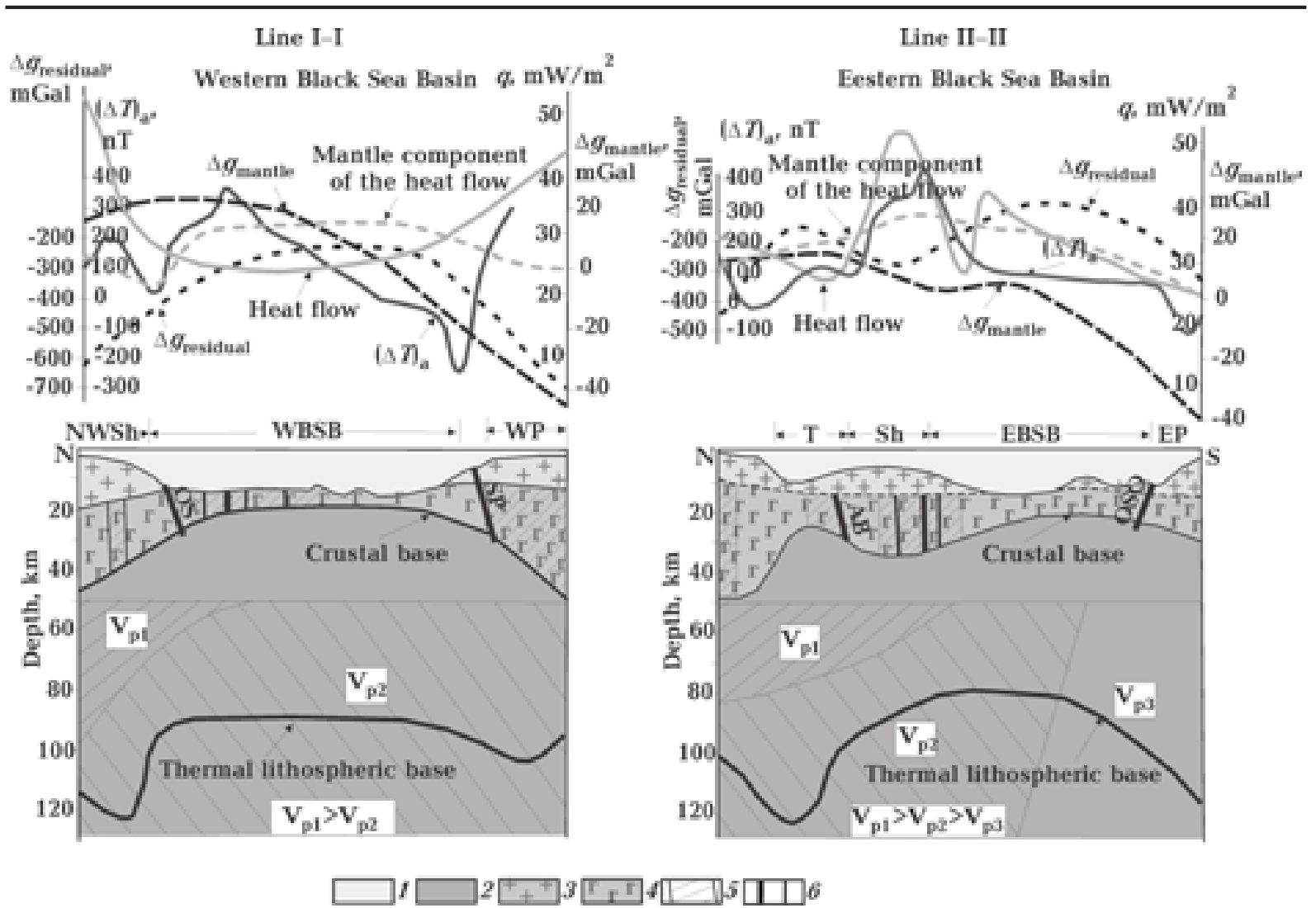

Fig. 16. Lithospheric schematic cross-sections through the Black Sea Basins from geophysical data (location of profiles is shown in Fig. 15): 1 - water and sediments, 2 - upper mantle, 3 - «granitic» layer, 4 - «basaltic» layer, 5 - magnetized blocks, 6 local magnetic sources. $V_{P}$ - seismic velocity [Bugaenko et al., 2008] for mantle deeper $50 \mathrm{~km}$ level. WP — Western Pontide, EP — Eastern Pontide. For other abbreviations see Fig. 11.

It can be seen that the lithosphere is significantly thinned beneath the «non-granitic» crust and the Moho uplift is observed in both basins. However, in the WBSB where the topography of the lithospheric lower boundary is flat, its thickness is ca. $90 \mathrm{~km}$ increasing to $110-120 \mathrm{~km}$ in peripheral areas as well as outside the basin. Beneath the EBSB the lithospheric thickness is similar $(80 \mathrm{~km})$ but its lower boundary is domed, the maximum uplift being shifted from the centre to the north. The dome shape of the lithospheric lower boundary in the eastern depression seems to reflect the occurrence of a separate asthenospheric bulge beneath it. In the southern parts of both sub-basins the low-density mantle exists whilst an increase in density occurs in the crust. The low-density mantle are characteristic of two sub-basins. A prominent local heat flow anomaly relates to the rift zone in the EBSB. Heat flow of the rift zone forms a broad low, which occupies mostly the WBSB. Patterns of $P$-wave at a $35-85 \mathrm{~km}$ depth revealed differences in the lithosphere structure of the WBSB and EBSB [Yegorova et al., 2013]. There are also velocity perturbations beneath a depth of
$50 \mathrm{~km}$ in the Black Sea lithosphere [Bugaenko et al., 2008]. Their northern and southern areas are characterized by high and low velocities respectively. The boundary between them has a northern dip down to a depth of $100 \mathrm{~km}$ (see Fig. 16). Near the southern boundary of the eastern basin, a discontinuity is also recognized in the velocity pattern. The intensity of the mantle component is strongly correlated with a variation in the values of $V_{P}$ in the lithosphere.

A direct relationship exists between the increased gravity mantle component (see Fig. 5) and the relative highs of the crustal gravity effects (see Fig. 7) in the EBSB where «basaltic» crust occurs. In the WBSB a relative maximum of the gravity residuals spatially coincides with the similar crust type but it does not manifest itself in the mantle component. DSS data from these areas have consistently revealed a crustal velocity of 6.8-7.2 $\mathrm{kms}^{-1}$ [Balavadze et al., 1975; Scott, 2009]. This situation seems to be caused by the occurrence of mafic material in the lower crust.

The geometry of the WBSB is clearly marked by steep gradients of the residual gravity field pro- 
duced by the crystalline crust (see Fig. 7). This observation evidences that the faults of the crystalline crust control the boundaries of the western sub-basin. In contrast, the outline of the eastern sub-basin is not delineated by any geophysical parameter observed.

Collectively, the substantial differences in the crustal and mantle structure and parameters between the western and eastern depressions of the present-day Black Sea show clear evidence for their independent distinctive evolution (Table). This inference does not contradict the model involving rifting of thermally and mechanically different lithosphere beneath the Black Sea subbasins [Spadini et al., 1996]. Seismic tomography revealed different structure velocity of the lithosphere up to $150 \mathrm{~km}$ depth in the EBSB and WBSB [Bugaenko et al., 2008; Yegorova, Gobarenko, 2010; Yegorova et al., 2013].

The dissimilarity seems to result mainly from the pre-existence of the long-live OSO fault zone, which is responsible for the division of the Black Sea into two individual basins. The opening of the Black Sea started on the continental crust consisting of terrains with different ages and sizes later accreted by tectonic events [Winchester et al., 2006; Yegorova et al., 2010].

As the OSO fault zone was the oldest dominant tectonic feature in the region, it separated two large crustal domains from initiation and termination of the Black Sea formation. The OSO fault is of mantle origin and long active tectonic feature. It is manifested in the mantle gravity component (see Fig. 5) and in isolines on the maps of the crust-mantle boundary, tops of CretaceousEocene sedimentary horizons generally following the strike of this feature in its zone [Kravchenko et al., 2003]. The last rejuvenation of this zone may occur during the Neoalpine stage because its general trend is concordant with that of the northern fragment of this front (see Fig. 11, p. 8) Numerous gas-venting sites are spatially related to it that conforms recent activity of the OS fault zone [Kutas et al., 2004].

A scenario of the Black Sea development strongly resembles that one of the Dnieper-Donets Depression [Chekunov et al., 1992; Stephenson, Stovba, 2012]. The rift was developed on the cold Pracambrian continental crust with a system of north-northeast trending pre-rift deep faults. Reactivation of these faults during the Paleozoic caused differntial subcidence of crustal domains and their geological structure. The rifting stage lasted for ca. $40 \mathrm{Ma}$.

The present-day imprints of rifting can be seen on oblique bands of the rift-related magnetic sources with a NE and NW strike in the WBSB and EBSB respectively (see Fig. 3, 10, p. 7). Such an obliquity mode of rifting zones in the Black Sea has the remarkable similarities with that one in the Red Sea and Gulf of Aden [Besutiu, Zugravesku, 2004]. Obliquity of rifts strongly suggests a time lag between opening the Black Sea sub-basins. The different shapes of the lithospheric lower boundary in the Black Sea sub-basins (see Fig. 16) produce further evidence in the occurrence of the separate asthenospheric bulges beneath them.

Despite much efforts to unequivocally reconstruct the evolution of the Black Sea, the relative age of its sub-basins has been disputable for many years [for example, Zonenshain, Le Pishon, 1986; Okay et al., 1994; Nikishin et al., 2003; Kaimakci et al., 2014]. However, high precision paleontological data revealed the accurate dating of the opening of its sub-basins [Hippolyte et al., 2010]. Based on 164 nannoplankton ages from the inverted margin of the Black Sea Basin in the Central Pontides, subsidence rifting of its

\section{Geophysical parameters of the lithosphere of the WBSB-and EBSB [Modified from Starostenko et al., 2010]}

\begin{tabular}{|l|l|l|}
\hline \multicolumn{1}{|c|}{ Geophysical parameters } & \multicolumn{1}{|c|}{ Western basin } & \multicolumn{1}{c|}{ Eastern basin } \\
\hline $\begin{array}{l}\text { Orientation of major faults } \\
\text { Configuration of basin }\end{array}$ & NE (mantle origin) & NW (crustal origin) \\
M-discontinuity relief & Approximately isometric & NW elongate \\
Crust composition & High up to $19 \mathrm{~km}$ & Asymmetric high up to $22 \mathrm{~km}$ \\
Magnetic anomalies & Basic & Basic only in the central part \\
$\Delta g$, residual & Linear, NE & Linear, NW \\
$\Delta g$, mantle & $+(100-250) \mathrm{mGl}$ & $+(100-150) \mathrm{mGl}$ \\
$V_{P}$ of the mantle & $+40 \mathrm{mGl}$ & $+30 \mathrm{mGl}$ \\
Heat flow density & Constant & Increasing from S to N \\
Relief of the thermal lithosphere & Homogeneous & Differentiated \\
Tectonic pattern & Homogeneous structure & Dome-like, up to $80 \mathrm{~km}$ \\
& & Differentiated structure \\
\hline
\end{tabular}


west part started in the Upper Barremian and lasted ca. 40 Ma years to Coniacian. Constraints from seismic reflection data suggest that rifting phase in the WBSB occurred over up to $30 \mathrm{Ma}$ after beginning in the Middle Barremian [Spadini et al., 1996]. These durations are also consistent with modeling thermal history of rifting event (ca. $40 \mathrm{Ma}$ ) in the Western Black Sea [Kutas, 2003]. Age determinations from nannoplankton confirm the diachronous opening of the Black Sea subbasins, with rifting of the EBSB beginning in the Paleocene-Eocene time [Hippolyte et al., 2010]. Eastern Black Sea in its present form rifted after the Early Paleocene (Danian) as inferred from integration of stratigraphic relationship from petroleum exploration boreholes in Georgia, results of dredging the seafloor north of the Turkish coast and dating the deepest part of the post-rift infill in sea area [Spadini et al., 1996].

5. Summary and conclusions. The opening and evolution of the Black Sea basin have been disputable during many decades due to lack of adequate information on peculiarities of its deep structure. To fill this gap gravity, magnetic, heat flow, seismic and tomographic data have been subjected to a joint analysis for the first time. 3D modeling technique resulted in new information on a relationship between a density image in the consolidated crust and the upper mantle. Based on interdisciplinary examination of geophysical data, the enough detailed map of faults was compiled for the crystalline crust. It sheds new light on a penetration depth of faults and their role in the origination and evolution of the Black Sea basins as well as on their linkage with surrounding tectonic features on land. A new and consistent picture of lithospheric density, magnetic, thermal and velocity heterogeneities was obtained. A substantial difference exists in the crustal and mantle structure and geophysical parameters of the WBSB and EBSB.

This dissimilarity is as follows. The «non-granitic» crust occurs only in the central portion of the EBSB whereas it spreads practically within

\section{References}

Afanasenkov A. P., Nikishin A. M., Obukhov A. V., 2007. The Eastern Black Sea Basin: geological structure and hydrocarbon potential. Moscow: Nauchny Mir, 172 p. (in Russian).

Akbayram K., Okay A., Stir M., Topuz G., 2009. New U-Pb and Rb-Sr ages from northwest Turkey; Early Cretaceous continental collision in the western Pontides. the whole WBSB. Heat flow is more intensive and differentiated in the EBSB than in the WBSB. The topography of the thermal lithospheric lower boundary is dome-like beneath the EBSB and it is flat in the WBSB. Different mantle seismic velocities as well as the fabric of the crustal magnetic and gravity anomalies are characteristic of the two sub-basins. Over the rift zone a distinct local heat flow anomaly is observed in the Eastern Black Sea basin. On the contrary, in the WBSB the rift zone is not individually manifested itself in thermal field. The low-density mantle exists beneath the rift zone in the EBSB whereas any distortions of a density distribution are related to similar zone in the Western Black Sea Basin. The latter observation evidences for an earlier stabilization of thermo-tectonic activity in the western sub-basin than in the eastern one.

The large mantle fault zones have been reliably delineated in the Black Sea with the prominent OSO faults zone, which has mostly predetermined the dissimilarities mentioned because it has divided the old continental crust into two large blocks. The OSO is the Precambrian tectonic disruption in the crystalline crust of the Black Sea, with it tectonic activity is continuing up to now. Obliquity of the rifts in the Western and Eastern Black Sea Basins clearly demonstrates that these depressions were diachronously formed as two separate tectonic units with their post-rift autonomous and individual histories. The An Ridge is formed by the stretched continental crust and the Ar Ridge is composed of the thickened ocean crust. The Sin Trough resulted from the Late Miocene incipient dextral strike-slip motion of the North Anatolian Fault.

Acknowledgments. Many thanks to Prof. Dr. N. Kaymakci (Middle East Technical University, Ankara, Turkey) for the insightful comments of the earlier version of the manuscript. Our appreciation is due to Dr. T. Yegorova (Institute of Geophysics, National Academy of Sciences of Ukraine) for her critical review and help in editing the English of this paper.

Geophysical Research Abstracts, 11, EGU2009-7395-2.

Aryamanesh A., 2009. Aeromagnetic Data Interpretation to Locate Buried Faults in Yazd Province - Iran. World Appl. Sci. J. 10, 1429-1432.

Balavadze B. K., Belokurov V. S., Garkalenko I. K., Malovitsky Yu. P., Mindeli P. Sh., Moskalenko V. N., 
Neprochnov Yu. P., Neprochnova A. F., Starshinova E. A., Chekunov A. V., 1975. Physical properties of rocks Black Sea basin. In: The Earth's crust and the Black Sea basin evolution. Eds Yu. D. Bulanzhe, M. V. Muratov, S. I. Subbotin, B. K. Balavadze. Moscow: Nauka, 254-269 (in Russian).

Belousov V. V., Volvovsky B. S., Arkhipov I. V., Buryanov V. B., Evsyukov Y. D., Goncharov V. P., Gordienko V. V., Ismagilov D. F., Kislov G. K., Kogan L. I., Kondyurin A. V., Kozlov V. N., Lebedev L. I., Lokholatnikov V. M., Malovitsky Y. P., Moskalenko V. N., Neprochnov Y. P., Ostisty B. K., Rusakov O. M., Shimkus K. M., Shlezinger A. E., Sochelnikov V. V., Sollogub V. B., Solovyev V. D., Starostenko V. I., Starovoitov A. F Terekhov A. A., Volvovsky I. S., Shigunov A. S., Zolotarev V. G., 1988. Structure and evolution of the Earth's crust and upper mantle of the Black Sea. Boll. Geofis. Teor. Appl., 30 (117-118), $109-196$.

Besutiu L., Zugravescu D., 2004. Geophysical considerations on the Black Sea opening and its seismotectonic consequences. Rev. Roum. Géophysique 48, 3-13.

Bezverkhov B. D., 1988. Tectonics of the Mesozoic sedimentary cover in the NW as a basis for planning oil and gas exploration. Ph.D. Thesis. Odessa University, Ukraine (in Russian).

Bozkurt E., Winchester J. A., Piper J. D. A. eds., 2000. Tectonics and Magmatism in Turkey and Surrounding Area. Geol. Soc. London Spec. Publ., 173. 540 p.

Brocher T. M., 2005. Compressional and Shear Wave Velocity versus Depth in the San Francisco Bay Area, California: Rules for USGS Bay Area Velocity Model 05.0.0. Open-File Report 05-1317. Menlo Park, Calif., US Geological Survey. 58 p.

Bugaenko I. V., Shumlyanskaia L. A., Zaets L. N., Tsvetkova T. A., 2008. Three dimensional $P$-velocity model for the mantle of the Black Sea and adjacent territory. Geophys. J. 30(5), 145-160 (in Russian).

Bulanzhe Yu. D., Muratov M. V., Subbotin S. I., Balavadze B. K. eds., 1975. The Earth's crust and history of evolution of the Black Sea Depression. Moscow: Nauka, 258 p. (in Russian).

Buryanov V. B., Kozlenko V. G., Rusakov O. M., 1981. An universal reducing model for interpretation of gravity anomalies in a fitting method. Reports of Academy of Sciences of Ukrainian Soviet Socialist Republic, Series. B. 5, 3-6 (in Russian).

Carslaw H. S., Jaeger J. C., 1959. Conduction of heat in solids. 2nd ed. Oxford: Clarendon Press, 510 p.

Čermak V., Bodri L., Rybach L., Buntebarth G., 1990. Relationship between seismic velocity and heat production: comparison of two sets of data and test of validity. Earth Planet. Sci. Lett. 99, 48-57.
Chekunov A. V., 1987. Problems of the Black Sea depression. Geophys. J. 9(4), 3-25 (in Russian).

Chekunov A. V. ed., 1994. The lithosphere of the Central and Eastern Europe: Young platforms and the Alpine folded belt. Kiev: Naukova Dumka, 331 p. (in Russian).

Chekunov A. V, Gavrish V. K., Kutas R. I., Ryabchun L. I., 1992. Dniepr-Donetsk paleorift. In: The lithosphere of the Central and Eastern Europe: Young platforms and the Alpine folded belt. Chekunov A. V. ed., Kiev: Naukova Dumka, 331 p. (in Russian).

Çinku M. C, Mümtaz H., Orbay N., Ustaömer T., Hirt A., Kravchenko S., Rusakov O., Sain N., 2013. Evidence of Early Cretaceous remagnetization in the Crimean Peninsula: a palaeomagnetic study from Mesozoic rocks in the Crimean and Western Pontides, conjugate margins of the Western Black Sea. Geophys. J. Int. 195, 821-843.

Christensen N. I., Mooney W. D., 1995. Seismic velocity structure and the composition of the continental crust: A global view. J. Geophys. Res. 100, 9761-9788.

Cloetingh S., Spadini G., van Wees J. D., Beekman F., 2003. Thermo-mechanical modelling of Black Sea Basin (de)formation. Sediment. Geol. 156, 169-184.

Coles R. L., Haines G. V., Jansen van Beek G., Nandi A., Walker J. K., 1982. Magnetic anomaly maps from $40^{\circ} \mathrm{N}$ to $83^{\circ} \mathrm{N}$ derived from MAGSAT satellite data. Geophys. Res. Lett. 9, 281-284.

Dimitriu R. G., Seghedi A., Sava S. C., Oaie G., 2000. Geotectonic frame outlined by 3D interpretation of geophysical data in Danube delta region (Romania). Romanian Geophys., 7, 114-117.

Dziewonsky A. M., Anderson D. I., 1981. Preliminary reference Earth model. Phys. Earth Planet. Int. 25, $297-356$.

Finetti I., Bricchi G., Del Ben A., Pipan M., Xuan Z., 1988. Geophysical study of the Black Sea area. Boll. Geofis. Teor. Appl. 30 (117-118), 197-324.

Galushkin Yu. I., Shreider A. A., Bulychev A. A., Shrei$\operatorname{der} A$ l. A., 2006. Heat flow and thermal evolution of the Black Sea lithosphere. Oceanology 46, 274-29.

Gardner G. H. F., Gardner L. W., Gregory A. R., 1974. Formation velocity and density. The diagnostic basics for stratigraphic traps. Geophysics 39, 770 - 780 .

Georgiev G., 2012. Geology and Hydrocarbon Systems in the Western Black Sea. Turkish J. Earth Sci. 21, $723-754$.

Graham R., Kaymakci N., Horn B. W., 2013. The Black Sea: Something different? Geo ExPro 10, 58-66. 
Grant F. S., West G. F., 1966. Interpretation Theory in Applied Geophysics. Instituto de libro, № 1002, Vedado Habana. 584 p.

Guzhikov A. Yu., Arkad'ev V. V., Baraboshkin E. Yu., Bagaeva M. I., Piskunov V. K., Rud'ko S. V., Perminov V. A., Manikin A. G., 2012. New Sedimentological, Bio- and Magnetostratigraphic Data on the Jurassic-Cretaceous Boundary Interval of Eastern Crimea (Feodosiya). Stratigraphy and Geological Correlation 20, 261-294.

Haines G. V., 1985. Magsat vertical field anomalies above $40^{\circ} \mathrm{N}$ from spherical Cap Harmonic Analysis. J. Geophys. Res. 90, 2593-2598.

Hammer $S ., 1963$. Deep gravity interpretation by stripping. Geophysics 3, 369-378.

Harvey P. K., Brewer T. S., Pezard P. A., Petrov V. A. eds., 2005. Physical Properties of crystalline Rocks. Geol. Soc. London Spec. Publ. 240, 351 p.

Hippolyte J. -C., Muller C., Kaymakci N., Sangu E., 2010. Dating of the Black Sea Basin: new nannoplankton ages from its inverted margin in the Central Pontides (Turkey). In: Sedimentary Basin Tectonics from the Black Sea and Caucasus to the Arabian Platform. Eds. M. Sosson, N. Kaymakci, R. A. Stephenson, F. Bergerat, V. Starostenko. Geol. Soc. London Spec. Publ. 340, 113-136.

Kaymakci N., Duermeijer C. E., Langreis C., White S. H., van Dijk P. M., 2003. Paleomagnetic evolution of the Çankiri Basin (central Anatolia, Turkey): implications for oroclinal bending due to indentation. Geology Magazine 140, 343-355.

Kaymakci N., Graham R., Bellingham P., Horn B. W., 2014. Geological Characteristics of Black Sea Basin: Inferences from New Black Sea Seismic Data. AAPG Datapages/Search and Discovery Article 90194. International Conference \& Exhibition, Istanbul, Turkey, September 14-17, 2014.

Khriachtchevskaia O., Stovba S., Popadyuk I., 2009. Hydrocarbon prospects in the Western Black Sea of the Ukraine. The Leading Edge 28(9), 1024-1029.

Kozlenko Yu. V., Kozlenko M. V., Lysynchuk D. V., 2009. Interdisciplinary seismic structural modelling hydrocarbon prospective structures in the western Black Sea. Geology and mineral recourses of the World Ocean 3, 25-34 (in Russian).

Kravchenko S. N., Orlyuk M. I., Rusakov O. M., 2003. A new approach to interpreting the regional Western Black Sea magnetic anomaly. Geophys. J. 25(2), 135-144 (in Russian).

Kutas R. I., 2003. Analysis of thermomechanic models of the Black Sea sedimentary evolution. Geophys. J. 25(2), 36-47 (in Russian).
Kutas R. I., 2010. Geothermal conditions of the Black Sea basin and its adjacent areas. Geophys. J. 32(6), 135-158 (in Russian).

Kutas R. I., Kobolev V. P., Bevzyuk M. I., Kravchuk O. P., 2003. New heat flow determinations in the NW Black Sea. Geophys. J. 25(2), 48-53 (in Russian).

Kutas R. I., Kobolev V. P., Bevzyuk M. I., Kravchuk O. P., 1999. Results of the heat flow determinations in the NW sector of the Black Sea basin. Geophys. J. 19(6), 70-83 (in Russian).

Kutas R. I., Kobolev V. P., Tsvyaschenko V. A., 1998. Heat flow and geothermal model of the Black Sea depression. Tectonophysics 291, 91-100.

Kutas R. I., Tsvyaschenko V. A., 1993. Influence of sedimentation on the heat field of the Black Sea depression. Geophys. J. 15(1), 32-34 (in Russian).

Kutas R. I., Tsvyaschenko V. A., Korchagin I. N., 1989. Heat field modeling of the continental lithosphere. Kiev: Naukova Dumka, 191 p. (in Russian).

Kutas R. I., Palyi S. I., Rusakov O. M., 2004. Deep faults, heat flow and gas leakage in the northern Black Sea. Geo-Mar. Lett. 24, 163-168.

Kutas R., Poort J., 2008. Regional and local geothermal conditions in the southern Black Sea. Int. J. Earth Sci. 97, 353-363.

Kutas R., Poort J., Klerx J., Kravchuk O., Bevzyuk M., 2005. Geothermal conditions in zones of gas escape and mud volcanism in northern Black Sea. Geophys. J. 27(1), 128-135.

Makarenko I. B., 1997. Earth's crust structure of the Black Sea basin as inferred from gravity modelling. PhD Thesis. Instutute of Geophysics, National Academy of Sciences of Ukraine, Kiev.

Mavko G., Mukerji T., Dvorkin J., 2009. The Rock Physics Handbook. Tools for Seismic Analysis of Porous Media. New York: Cambridge University Press. 511 p.

Nikishin A. M., Okay A., Tüysüz O., Demirer A., Wannier M., Amelin N., Petrov E., 2015a. The Black Sea basins structure and history: New model based on new deep penetration regional seismic data. Part 1: Basins structure and fill. Marine and Petroleum Geology 59,636-655.

Nikishin A. M., Okay A., Tüysüz O., Demirer A., Wannier M., Amelin N., Petrov E., 2015b. The Black Sea basins structure and history: New model based on new deep penetration regional seismic data. Part 2: Tectonic history and paleogeography. Marine and Petroleum Geology 59, 656-670.

Nikishin A. M., Korotaev M. V., Ershov A. V., Brunet M. F., 2003. The Black Sea basin: tectonic history and Neogene-Quaternary rapid subsidence modelling. Sedimentary Geology 156, 149-168. 
Nikishin A. M., Ziegler P. A., Bolotov S. N., Fokin P. A., 2011. Late Palaeozoic to Cenozoic Evolution of the Black Sea-Southern Eastern Europe Region: A View from the Russian Platform. Turkish J. Earth Sci. 20, $571-634$.

Nikishin A. M., Khotylev A. O., Bychkov A. Yu., Kopaevich F., Petrov E. I., Yapaskurt V. O., 2013. Cretaceous Volcanic Belts and the Evolution of the Black Sea. Moscow University Geology Bull. 68, 141-154.

Okay A. I., Sengör A. M. C., Görür N., 1994. Kinematic history of the opening of the Black Sea and its effect on the surrounding regions. Geology 22, 267-270.

Pashkevich I. K., Mozgovaya A. P., Orlyuk M. I., 1993. Three-dimensional magnetic model for Crimea and adjacent areas: application to seismic zoning. In: Geodynamics and deep structure of the seismogenetic zones in Ukraine. Ed. A. V. Chekunov. Kiev: Naukova Dumka, 9-18 (in Russian).

Pashkevich I. K., Orlyuk M. I., Bogdanova S. V., 1995. Large-scale magnetic segments of Europe, their juncture zones and relationships with tectonic units. $9^{\text {th }}$ meeting of the Association of European Geological Societies. Precambrian Europe: Stratigraphy, Structure Evolution and Mineralization. St. Petersbourg, 85-86.

Piip V. B., Ermakov A. P., 2011. Oceanic crust of the Black Sea Basin based on seismic data. Moscow University Geology Bull. 66, 61-68.

Pivovarov V. P., Logvin V. N., 2001. On interactive fitting of a seismo gravity model and relationship of «velocity/density» along CMRW-DSS profiles of Azov-Black Sea region. Abstracts. $3^{\text {rd }}$ international conference «Crimea-2001» Simferopol, «Tavriia Plus». 122-124.

Rangin C., Bader A. G., Pascal G., Ecevitoğlu B., Görür N., 2002. Deep structure of the Mid Black Sea High (offshore Turkey) imaged by multi-channel seismic survey (BLACKSIS cruise). Marine Geology $182,265-278$.

Robinson A. G. ed., 1997. Regional and Petroleum Geology of the Black Sea and Surrounding Region. American Association of Petroleum Geologists Memoir. 68, 385 p. Ross D. A., 1978. Summary of results of Black Sea drilling. Init. Rep. DSDP XLII, 1149-1177.

Rybach L., 1996. Heat sources, heat transfer, and rock types in the lower continental crust-inference from deep drilling. Tectonophysics 257, 1-6.

Ross D. A., 1978. Summaryof results of Black Sea drilling. Init. Rep.DSDP, XLII. 1149-1177.

Rybach L., Buntebarth G., 1982. Relationship between the petrophysical properties, density, seismic velo- city, heat generation and mineralogical constitution. Earth Planet. Sci. Lett. 57, 367-376.

Saintot A., Stephenson R. A., Stovba S. M., Brunert M.F., Yegorova T., Starostenko V., 2006. The evolution of the southern margin of Eastern Europe (Eastern European and Scythian platforms) from the latest Precambrian-Early Palaeozoic to the Cretaceous. In: European Dynamics Lithosphere. Eds. D. G. Gee, R. A. Stephenson. Geol. Soc. London Memoir. 32, $481-505$

Sandwell D. T., Smith W. H. F., 2009. Global marine gravity from retracked Geosat and ERS-1 altimetry: Ridge Segmentation versus spreading rate. J. Geophys. Res. 114, B01411. doi:10.1029/2008JB006008.

Sclater J. G., Jaupart C., Galson D., 1980. The heat flow through oceanic and continental crust and the heat loss of the earth. Rev. Geophys. Space Phys. $18,269-311$.

Scott S. L., 2009. Formation and evolution of the eastern Black Sea Basin: constraints from wide-angle data. Ph. D. Thesis. Southampton University, UK.

Scott S. L., Shillington D. J., Minshull T. A., Edwards R. A., Brown P. J., White N. J., 2009. Wide-angle seismic data reveal extensive overpressure in the Eastern Black Sea Basin. Geophys. J. Int. 178, 1145-1163.

Shillington D. J., Scott S. L., Minshul T. A., Edwards R. A., Brown P. J., White N. J., 2009. Abrupt transition from magma-starved to magma-rich rifting in the EasternBlack Sea. Geology 75, 7-10.

Shreider A. A., Kazmin V. G., Lygyn V. S., 1997. Magnetic anomalies and the problem of an age of the Black Sea Basin. Geotectonics 31, 54-64.

Slishinsky S. B., Zhadan A. M., Popadyuk I. V., 2007. Preliminary results of regional seismic studies of CDPM within the Ukrainian sector of the Black Sea. Problems of oil and gas industry. Collection of scientific transactions. Kyiv, Issue 5, 140-147 (in Ukrainian).

Smith R. P., Grauch V. J. S., Blackwell D. D., 2002. Preliminary Results of a High-Resolution Aeromagnetic Survey to Identify Buried Faults at Dixie Valley, Nevada. Geothermal Resources Council Transactions $26,543-546$.

Sollogub V. B. ed., 1987. The Geology of the USSR shelf. Tectonics. Kiev: Naukova Dumka, 153 c. (in Russian).

Spadini G., Robinson A., Cloetingh S., 1996. Western versus Eastern Black Sea tectonic evolution: pre-rift lithospheric controls on basin formation. Tectonophysics 266, 139-154.

Sreejith K. M., Radhakrishna M., Krishna K. S., Majumdar T. J., 2011. Development of the negative gravity anomaly of the $85^{\circ} \mathrm{E}$ Ridge, northeastern Indian 
Ocean - A process oriented modelling approach. J. Earth Syst. Sci. 120, 605-615.

Starostenko V., Buryanov V., Makarenko I., Rusakov O., Stephenson R., Nikishin A., Georgiev G., Gerasimov M., Dimitru R., Legostaeva O., Pchelarov V., Sava C., 2004a. Topography of the crust-mantle boundary beneath the Black Sea. Tectonophysics $381,211-233$.

Starostenko V. I., Dolmaz M. N., Kutas R. I., Rusakov O. M., Oksum E., Hisarli Z. M., Okyar M., Kalyoncuoglu U. Y., Tutunsatar H. E., Legostaeva O. V., 2014. Thermal structure of the crust in the Black Sea: comparative analysis of magnetic and heat flow data. Mar. Geophys. Res. 35, 345-359. doi 10.1007/ s11001-014-9224-X.

Starostenko V. I., Legostaeva O. V., 1998. Calculations of the gravity field from an inhomogeneous, arbitrary truncated vertical rectangular prism. Izvestiya, Physics of the Solid Earth 34(12), 991-1003.

Starostenko V. I., Legostaeva O. V., Makarenko I. B., Pavlyuk E. V., Sharypanov V. M., 2004b. On automated computing geologic-geophysical maps images with the first type breaks and interactive regime visualization of three-dimensional geophysical models and their fields. Geophys. J. 26(1), 3-13 (in Russian).

Starostenko V. I., Makarenko I. B., Rusakov O. M., Pashkevich I. K., Kutas R. I., Legostaeva O. V., 2010. Geophysical inhomogeneities of the Black Sea Megadepression. Geophys. J. 32(5), 3-20 (in Russian).

Starostenko V. I., Pashkevich I. K., Makarenko I. B., Rusakov O. M., Kutas R. I., Legostaeva O. V., 2005. Fault tectonics of the crystalline crust on the NW Black Sea shelf. Geophys. J. 27(2), 195-207 (in Russian).

Stephenson R. A., Stovba S. M., 2012. The DnieperDonets Basin. In: Regional Geology and Tectonics: Phanerozoic Rift Systems and Sedimentary Basins. Eds. D. G. Roberts, A. W. Bally. Oxford: Elsevier, Vol. 18, 421-441.

Stovba S. M., Khriachtchevskaia O. I., Popadyuk I. V., 2013. Crimea and Ukrainian Eastern Black Sea Basin as an Inverted Early Cretaceous Rift System. Eastern Black Sea and Caucasus Workshop. Abstracts Volume. June 24-25, 2013.Tbilisi, Georgia, 5-67.

Taylor P., Heirtzler J., Nazarova K., Pashkevich I., Orlyuk M., 1995. The nature of the Kursk Magnetic anomaly from modeling Magsat and aeromagnetic data. IUGG XXI General Assembly. Boolder. 5-14 August, 1995.

Tugolesov D. A., Gorshkov A. S., Meisner L. B., Solovyev V. V., Khakhalev E. M., 1985. Tectonics of Mesozoic-Cenozoic deposits of the Black Sea basin. Moscow: Nedra, 216 p. (in Russian).

Winchester J. A., Pharaon T. C., Verniers J., Ioann D., Seghedi A., 2006. Palaeozoic accretion of Gondwanaderived terranes to the East European Craton: recognition of detached terrane fragments dispersed after collision with promontories. In: European Lithosphere Dynamics. Eds. D. S. Gee, R. A. Stephenson. Geol. Soc. London Memoir 32, 323-332.

Wolberg J., 2005. Data Analysis Using the Method of Least Squares: Extracting the Most Information from Experiments. Berlin, Heidelberg: Springer-Verlag, $251 \mathrm{p}$.

Wyllie P. J., 1979. Magmas and volatile components. Amer. Mineral. 64, 469-500.

Yegorova T., Baranova K., Omelchenko V., 2010. The crustal structure of the Black Sea from the reinterpretation of deep seismic sounding data acquired in the 1960s. In: Sedimentary Basin Tectonics from the Black Sea and Caucasus to the Arabian Platform. Eds. M. Sosson, N. Kaymakci, R. A. Stephenson, F. Bergerat, V. Starostenko. Geol. Soc. London Spec. Publ. 340, 43-56.

Yegorova T., Gobarenko V., 2010. Structure of the Earth's crust and upper mantle of the West- and East Black Sea Basins Revealed from geophysical data and its tectonic implications. In: Sedimentary Basin Tectonics from the Black Sea and Caucasus to the Arabian Platform. Eds. M. Sosson, N. Kaymakci, R. A. Stephenson, F. Bergerat, V. Starostenko. Geol. Soc. London Spec. Publ. 340, 23-42.

Yegorova T., Gobarenko V., Yanovskaya T., 2013. Lithosphere structure of the Black Sea from 3-D gravity analysis and seismic tomography. Geophys. J. Int. 193(is. 1), 287-303. doi: 10.1093/gji/ggs098.

Ziegler P. A., 1982. Geological Atlas of Western and Central Europe. 2nd ed. Amsterdam: Shell Int. Petrol. Mij. B. V. and Elsevier Science Publ. 130 p. and 40 encl.

Zonenshain L. P., Le Pichon X., 1986. Deep basins of the Black Sea and Caspian Sea as remnant of Mesozoic back-arc basins. Tectonophysics 123, 181-211. 